MICHIGAN RETIREMENT AND DISABILITY RESEARCH CENTER UNIVERSITY OF MICHIGAN

Promoting research on retirement, disability, and Social Security policy

\title{
Macroeconomic Effects of Social Security Totalization Agreements
}

María J. Prados, Erik Meijer, and Francisco Pérez-Arce

MRDRC WP 2019-407

UM19-Q1 


\section{Macroeconomic Effects of Social Security Totalization Agreements}

\author{
María J. Prados \\ University of Southern \\ California
}

\author{
Erik Meijer \\ University of Southern \\ California
}

\author{
Francisco Pérez-Arce \\ University of Southern \\ California
}

\section{September 2019}

Michigan Retirement and Disability Research Center, University of Michigan, P.O. Box 1248. Ann Arbor, Ml 48104, mrrc.isr.umich.edu, (734) 615-0422

\section{Acknowledgements}

The research reported herein was performed pursuant to a grant from the U.S. Social Security Administration (SSA) funded as part of the Retirement Research Consortium through the University of Michigan Retirement Research Center Award RDR18000002. The opinions and conclusions expressed are solely those of the author(s) and do not represent the opinions or policy of SSA or any agency of the federal government. Neither the United States government nor any agency thereof, nor any of their employees, makes any warranty, express or implied, or assumes any legal liability or responsibility for the accuracy, completeness, or usefulness of the contents of this report. Reference herein to any specific commercial product, process or service by trade name, trademark, manufacturer, or otherwise does not necessarily constitute or imply endorsement, recommendation or favoring by the United States government or any agency thereof.

\section{Regents of the University of Michigan}

Jordan B. Acker; Huntington Woods; Michael J. Behm, Grand Blanc; Mark J. Bernstein, Ann Arbor; Paul W. Brown, Ann Arbor; Shauna Ryder Diggs, Grosse Pointe; Denise llitch, Bingham Farms; Ron Weiser, Ann Arbor; Katherine E. White, Ann Arbor; Mark S. Schlissel,s ex officio 


\title{
Macroeconomic Effects of Social Security Totalization Agreements
}

\begin{abstract}
The United States has signed international social security totalization agreements with 30 countries. For persons working in a foreign country during part of their careers, these agreements reduce double taxation on social security burdens and reduce the risk of not qualifying for social security benefits. In this report, we consider the potential of international social security totalization agreements to affect macroeconomic outcomes. We find that these agreements are associated with higher levels of foreign direct investment. The theoretical framework indicates that these treaties can affect firms' decisions to relocate their activities across borders, but the magnitude and direction of this effect depends on the characteristics of the countries involved. The effects of these agreements are larger when the share of foreigncontrolled production is smaller in the host country.
\end{abstract}

\section{Citation}

Prados, Maria J., Erik Meijer, and Francisco Pérez-Arce. 2019. "Macroeconomic Effects of Social Security Totalization Agreements." Ann Arbor, MI. University of Michigan Retirement and Disability Research Center (MRDRC) Working Paper; MRDRC WP 2019-407. https://mrdrc.isr.umich.edu/publications/papers/pdf/wp407.pdf

\section{Authors' acknowledgements}

This paper uses data from SHARE Wave 1. [The SHARE data collection has been funded by the European Commission through FP5 (QLK6-CT-2001-00360), FP6 (SHARE-I3: RII-CT-2006062193, COMPARE: CIT5-CT-2005-028857, SHARELIFE: CIT4-CT-2006-028812), FP7 (SHARE-PREP: GA N²11909, SHARE-LEAP: GA N²27822, SHARE M4: GA N²61982) and Horizon 2020 (SHARE-DEV3: GA N676536, SERISS: GA N654221) and by DG Employment, Social Affairs \& Inclusion. Additional funding from the German Ministry of Education and Research, the Max Planck Society for the Advancement of Science, the U.S. National Institute on Aging (U01_AG09740-13S2, P01_AG005842, P01_AG08291, P30_AG12815, R21_AG025169, Y1-AG-4553-01, IAG_BSR06-11, OGHA_04-064, HHSN271201300071C) and from various national funding sources is gratefully acknowledged (see www.share-project.org).] We are thankful to Arie Kapteyn for useful comments and to Dongwook Kim for outstanding research assistance. We are grateful to Brent Jackson at SSA for providing us with useful data. 


\section{Introduction}

The United States has signed international social security treaties regarding the treatment of temporary foreign workers - called totalization agreements - with 30 countries in Europe, Asia, North and South America, as well as Australia. These agreements typically state that the host country refrains from social security taxation of temporary foreign workers and that the sender country recognizes the foreign deployment in determining eligibility for and amount of social security benefits. Totalization agreements have several benefits for persons who work in a foreign country during part of their careers. A totalization agreement between the U.S. and a partner country mainly helps nationals of either working in the foreign country by letting them avoid dual contributions to the social security systems of the U.S. and of the other country, and by reducing the risk of not meeting their home country's eligibility requirements (such as the minimum number of years of contributions).

Totalization agreements' advantages may go beyond those accruing to such workers. By making it less costly for workers - and their employers - to move abroad for periods of time, totalization agreements can encourage economic activity. Firms may be more likely to invest in a country with a totalization agreement, as the cost of temporarily reallocating labor is lower and their employees may be more willing to temporarily work abroad to oversee the firm's investment or their foreign affiliates. Because this is true for both countries participating in the agreement, foreign investment in both countries may increase. As in the case of reducing trade barriers, lowering obstacles to labor mobility with a totalization agreement may thus result in improved efficiency and economic outcomes for both the U.S. and the partner country. This project's goal is to investigate totalization agreements' economic effects. In particular, 
we aim to answer the question: "What are the effects of totalization agreements on foreign capital movements and investment flows?"

Multinational production — rather than international trade — has become the dominant way through which firms serve foreign consumers. Using data for the period 1982 to 2007 from the United Nations Conference on Trade and Development, Ramondo (2014) pointed out that, while world exports went from $19 \%$ to $31 \%$ of world GDP during this period, total sales of multinational firms' foreign affiliates increased from $24 \%$ of world GDP in 1982 to $58 \%$ in 2007 . During the same period, gross product of foreign affiliates as a share of world GDP more than doubled. These magnitudes suggest that multinational firms' foreign affiliates are more important than exports as the channel through which firms choose to serve foreign markets (Ramondo 2014), highlighting the importance of foreign direct investments (FDI). ${ }^{1}$ We will emphasize this channel as it is the most likely affected by totalization agreements.

In general, the economic literature supports the idea that taxes have important implications for the multinational firms' behavior. In particular, numerous papers have analyzed how FDI or new plant decisions are affected by corporate taxes, and they concluded that these taxes have a significant negative impact on foreign investment inflow. Existing elasticity estimates of outbound FDI with respect to corporate taxes take a wide range in the literature, with a median of around -3.3 (i.e., a $1 \%$ reduction in the host-country tax rate raises FDI in that country by $3.3 \%$ ), but estimates for inbound investment in the U.S. take a much lower value, of around -0.5 (De Mooij and Ederveen 2003).

\footnotetext{
${ }^{1}$ FDI flows refer to cross-border transactions related to direct investment. Outward (inward) flows represent transactions that increase the net investment investors in the source economy (foreign investors) have in enterprises in a foreign host economy (home economy).
} 
The problem under study here is more complex, because totalization agreements affect labor costs by impacting the incentives of workers and firms. A few research papers estimate FDI elasticity with respect to labor taxes. Egger and Radulescu (2011) looked at labor income taxes' effect on bilateral FDI flows using data from 52 countries. They found that foreign affiliates are less likely to be located in countries where average wage taxes and their progression are relatively high, and a higher employee-borne tax burden reduces managers' effort. However, they concluded corporate tax rates are more important for FDI decisions than labor tax rates. Hansson and Olofsdotter (2014) found the differential between two countries' top marginal labor tax rates has a negative impact on FDI — and this seems to have intensified over time. The literature has not paid much attention to the impact of social security taxation. An exception is the work by Egger et al. (2013), which used data for 79 countries in the years 1992 to 2009 to examine how labor taxes, including social security taxes, affect location choice for foreign affiliates' headquarters. The research showed that an increase in employer social security contributions of a single percentage point reduces the probability of foreign affiliates location by $5.5 \%$, more than three times greater than the effect found for income taxes (i.e., a similar percentage point increase leads to a reduction in the probability of a country as a potential headquarters location by $1.7 \%$ ).

Estimating totalization agreements' aggregate effects is empirically challenging, as these effects may be dwarfed by other macroeconomic factors, such as changes in exchange rates or demand shocks. Even if the agreements have substantial effects on those firms likely to establish affiliates abroad, for example, the aggregate effect may be low if the number of firms affected by totalization agreements is small. Therefore, to answer the research question of interest, we complement the data analysis with a 
model-based approach, relying on macroeconomic theory to evaluate this channel. Our approach consists of the following components:

1. an inventory of current and proposed totalization agreements and their main characteristics;

2. the analysis of existing data over time to detail the evolution of relevant macroeconomic phenomena, such as foreign capital movements and flow changes occurring around the time of the agreements;

3. an international macroeconomic model to understand more precisely the potential mechanisms through which agreements affect the economies of participating countries;

4. simulation of the quantitative effects of actual and counterfactual policies.

We find that the empirical evidence indicates that these totalization agreements are associated with higher amounts of U.S. FDI flows. The totalization agreements made multinational firms' reallocation of activities between the U.S. and the partner countries less expensive, and the model indicates that both inward and outward FDI flows should increase in the U.S. as a result. However, the agreements' net effects depend on the relative productivity and resources of the partner countries. Our simulation exercises show that these agreements increase incentives of American firms to engage in outward FDI in smaller economies, such as Chile, while the U.S. may become more receptive to capital and investment flows from foreign firms from larger economies or economies with higher taxes, such as Japan.

Section 2 provides a summary of the institutional background on totalization agreements. Section 3 includes a descriptive analysis of the available data. Section 4 describes the model used and performs quantitative exercises. Section 5 concludes. 


\section{Institutional background on totalization agreements}

We compiled an inventory of existing and proposed totalization agreements and analyzed their most important characteristics. The sources for these analyses are Jackson and Cash (2018) and the Internal Revenue Service ${ }^{2}$ and the Social Security Administration ${ }^{3}$ website pages for totalization agreements. Since 1978, the U.S. has signed totalization agreements with 30 countries.

Table 1 lists the agreements in which the U.S. participates and the effective date of each. In this section, we describe the main characteristics of these agreements and of the partner countries. We focus on the main aspects of the treaties that are expected to have an economic impact and on the calculation of their amounts. These aspects concern the elimination of dual social security coverage and taxation, which has implications for payroll and foreign income taxes as well as eligibility for social security benefits. This informs us about the kinds of workers most affected by the agreements and, thus, points to the potential channels through which these agreements affect economic activity.

\subsection{Similarities and differences across totalization agreements}

One could reasonably expect that content distinctions in the totalization agreements with different countries may result in heterogeneous impacts. Hence, we reviewed the content of the agreements. We found their similarities outweigh any differences. The goals of totalization agreements are similar across all, while dissimilarities are few across the topics meriting our attention. Perhaps the most

\footnotetext{
${ }^{2}$ https://www.irs.gov/individuals/international-taxpayers/totalization-agreements

${ }^{3}$ https://www.ssa.gov/international/agreements_overview.html
} 
important exception is Italy, where the totalization agreement allows some workers to choose the country to which they'll pay taxes and from which they'll draw benefits.

Table 1: List of countries with totalization agreements with the U.S.

\begin{tabular}{|c|c|}
\hline Country & Entry into Force \\
\hline Italy & November 1, 1978 \\
\hline Germany & December 1, 1979 \\
\hline Switzerland & November 1, 1980 \\
\hline Belgium & July 1,1984 \\
\hline Norway & July 1, 1984 \\
\hline Canada & August 1, 1984 \\
\hline United Kingdom & January 1, 1985 \\
\hline Sweden & January 1, 1987 \\
\hline Spain & April 1, 1988 \\
\hline France & July 1, 1988 \\
\hline Portugal & August 1, 1989 \\
\hline Netherlands & November 1, 1990 \\
\hline Austria & November 1, 1991 \\
\hline Finland & November 1, 1992 \\
\hline Ireland & September 1, 1993 \\
\hline Luxembourg & November 1, 1993 \\
\hline Greece & September 1, 1994 \\
\hline South Korea & April 1, 2001 \\
\hline Chile & December 1, 2001 \\
\hline Australia & October 1, 2002 \\
\hline Japan & October 1, 2005 \\
\hline Denmark & October 1, 2008 \\
\hline Czech Republic & January 1, 2009 \\
\hline Poland & March 1, 2009 \\
\hline Slovak Republic & May 1, 2014 \\
\hline Hungary & September 1, 2016 \\
\hline Brazil & October 1, 2018 \\
\hline Uruguay & November 1, 2018 \\
\hline Slovenia & February 1, 2019 \\
\hline Iceland & March 1, 2019 \\
\hline
\end{tabular}

Source: SSA

\subsubsection{Common aspects to most agreements}

We start by describing similarities across the agreements and how they may affect their economic impact. In our model, we will note a "home" or "source country" and a "host" or "destination country." However, in legal terms, which is the home country may not be so obvious as in our stylized model. 
In general, the principle in totalization agreements signed by the U.S. is that workers should pay taxes and be covered under the social security system of only one country, which is usually where they are employed — the territoriality rule. But there is an exception provided for workers sent to a country by their employer on a temporary assignment; this is referred to as the detached worker rule. To determine whether the detached worker rule exception applies for a specific worker, the totalization agreements refer to a concept of greater economic attachment. The agreements thus determine that individuals pay the social security taxes to the country determined to be the one with greater economic attachment and include rules on how to make that determination. ${ }^{4}$

\subsubsection{Rules about determination of greater economic attachment.}

Generalizing, an American worker sent abroad by an American employer with the intention of being there for fewer than five years will be determined to have greater economic attachment to the U.S., and so will contribute only to the U.S. Social Security system. But for people hired while in the foreign country or hired by a foreign-based firm, they will be deemed to have greater economic attachment to the foreign country (the same rules apply the other way around). ${ }^{5}$

\footnotetext{
${ }^{4}$ Source: IRS https://www.irs.gov/government-entities/federal-state-localgovernments/totalization-agreements

${ }^{5}$ A worker gets a certification from her "home" country. For example, when American firms send workers on temporary assignment for an affiliate in a partner country, the Social Security Administration can send these employees, through their employers, a certificate that acts as a tax declaration to demonstrate there is no need to pay the foreign nation's social security taxes. Self-employed workers based in America who work temporarily in another country can submit the request for a certificate themselves. It is necessary, however, that the selfemployed person intends to stay no longer than five years.
} 
Given this understanding of what totalization agreements do in practice, we determined the channels through which they affect workers (and, hence, firms and economic activity in general) are the following:

1. elimination of the double taxation incurred when a person must contribute to the social security system of both the home and host countries;

2. totalization of benefits, which reduces the risk of not qualifying to a pension due to "qualifying quarters" being spread across countries (Totalization agreements allow workers to combine, or "totalize," coverage credits from both nations.);

3. increasing workers' future pension amounts by allowing them to contribute to the social security system in the country that will eventually provide their benefits.

These three points guide our analysis and economic modeling in the sections ahead. Note, however, that one could not simply assign an economic value to each of the points above and add them up, as in most cases individuals will only benefit from one or two of the points above.

To understand this, consider the example of a worker contributing to two social security systems, the U.S. and that of a country where there is no totalization agreement in effect. A totalization agreement would benefit her by reducing the amount she pays in contributions to the two systems. But, in any case, she would not be at risk of not qualifying for a pension and, hence, would not be benefited by the second channel. Likewise, a totalization agreement would not increase the benefit amount she will eventually receive and, hence, she would not benefit from the third channel.

On the other hand, consider the alternative example of a worker who was not paying social security taxes in her home country, but was contributing to other countries' 
social security systems for periods too short to qualify for benefits. In that case, she would benefit from the totalization aspect of an agreement (points two and/or three) but not from point one.

From the modeling perspective, we note these three channels have more or less the same effect. That is, they reduce the cost of sending an employee to work in the partner country. This cost may be borne by the firm or the employee, or it may be shared. In a competitive labor market, the cost of the double taxation will be borne by the firms (which we discuss further in Section 4).

With social security programs having minimum contribution period amounts, and totalization agreements helping workers reach those minimums, this implies anomalies where some workers close to the threshold are very strongly affected while others (for example, those past the threshold) are not. In our model in Section 4, we abstract from these asymmetries.

The third channel also may imply some heterogeneity across workers because those with high subjective discount rates - or those who are inattentive to their retirement situation - may not value the pension benefits as much. (In those cases, their firms may not have to adjust payments as much when sending them to a country without a totalization agreement).

\subsubsection{Totalization agreement with Germany}

The Totalization Agreement with Germany was signed in 1979, the second such agreement signed by the U.S. The agreement covers retirement, disability, and survivor benefits and, hence, helps many people who without it would not be eligible for such benefits under the social security system of one the two countries.

If a person's work is covered by both the U.S. and German social security systems, the worker (and their employer) would normally have to pay social security 
taxes to both countries for the same work. The agreement eliminates this double coverage, so that taxes are paid to only one system. The U.S. Social Security tax is $12.4 \%$ (half of which is payable by the employer and half by the employee), for income that falls below US $\$ 132,900$ (in 2019). ${ }^{6}$ Germany social security taxes $18.7 \%$ of the first US $\$ 86,580$. Hence, the savings due to elimination of double SS-taxation can be substantial.

It also helps people who would otherwise have to pay other types of taxes, specifically Medicare taxes and analogous foreign taxes, to both countries on the same earnings. In the case of Germany, the totalization agreement covers the Medicare taxes and the corresponding taxes in Germany that finance Germany's sickness insurance and long-term nursing care programs.

If a person has Social Security credits in both the U.S. and Germany but does not have enough of them to be eligible for benefits in either country, the agreement makes it easier to qualify for benefits by letting the beneficiary add the Social Security credits in both countries. In the U.S., beneficiaries need a minimum of 10 years (40 quarterly credits), while in Germany they require at least five years. Take the example of an American sent to work in Germany for two years and who had accumulated 35 quarterly credits in the U.S. If she stops working upon her return to the U.S., she would not be able to claim Social Security retirement benefits absent a totalization agreement unless she had paid Social Security taxes in both countries during her time there. On the other hand, thanks to the totalization agreement, she would accumulate eight additional credits while in Germany as she would be covered by the U.S. system while

\footnotetext{
${ }^{6}$ Additionally, there is a $2.9 \%$ Medicare tax rate on earnings, which is not subject to the Social Security tax cap on earnings. An additional Medicare tax of $0.9 \%$ applies for income above $\$ 200,000$ (if filing single) or $\$ 250,000$ (if married, filing jointly).
} 
on assignment there. With the eight additional credits, she would have 43 total credits thereby qualifying for U.S. SS-retirement benefits.

\subsubsection{Totalization agreement with Chile}

As in the case of other totalization agreements, the one with Chile benefits people in one of two ways: the "eliminating dual coverage for employment" aspect that allows people to avoid paying SS-taxes in both countries and the "totalization" aspect that allows people to add the credits accumulated in both countries to satisfy the requirement for benefits in one of the countries. The Chilean agreement, in addition, means U.S. workers who are temporarily in Chile also do not need to pay taxes for national health insurance and workers' compensation.

Chile's case is interesting because it has implemented far-reaching reforms in its pension and social security system. Because the reforms are not retroactive, people born in different years are subject to different rules. The old Chilean system was a defined-benefit program. In order to qualify for retirement benefits, there was a 10-year contribution period requirement, as well as a requirement to have contributed within the two years of the time of retirement. The defined contribution program was established in 1980 and consists of individual accounts, but those who contribute for 20 years are eligible for a guaranteed minimum.

The "eliminating dual coverage for employment" aspect of the totalization agreement reduces firms' costs of sending workers to the partner country. For example, for an American resident temporarily sent to Chile to work, the totalization agreement means that the American worker does not need to open an individual pension account in Chile and make the obligatory contribution per Chilean law. For someone sent for a short period of time, having a pension account with only a few months or years of contributions may have little benefit and substantial administrative costs. Hence, 
allowing the worker to contribute only to her home-country system may lead to substantial savings and encourage bilateral investments across the two countries.

The totalization agreement between the U.S. and Chile includes non-national residents. Hence, the examples above apply to permanent residents in the U.S. and Chilean residents who are not citizens of either country as long as the "country of greater economic attachment" rule is satisfied. For example, a national of a third country who works for an American company in the U.S., but who is sent to work to Chile temporarily can apply (or have his company apply on his behalf) for a Certification of

Coverage from the U.S. SSA, which would allow him to avoid paying Social Security taxes while in Chile.

\section{$\underline{\text { 2.1.5 Differences }}$}

In most totalization agreements, the territoriality rule and detached worker rule serve to determine greater economic attachment. An exception to this is the agreement between the U.S. and Italy, which permits certain transferred workers to select the social security system under which they will be covered rather than it being assigned through the greater economic attachment rule (Jackson and Cash 2018). No other U.S. totalization agreement contains a similar rule.

Another source of variation across totalization agreements is the length of a "temporary" assignment. However, even in this dimension, there are few exceptions to the general rule. For most totalization agreements, the period of expected temporary assignment is five years or fewer, but, in some cases, they allow for one- or two-year extensions beyond the five-year period. Workers relocating permanently or for an 
intended period longer than five years should have coverage under the destination country's system. $^{7}$

A final source of variation is whether certain provisions of the totalization agreement covers only a country's citizens or also its permanent residents. Most agreements cover all residents per the rule of country of greatest attachment, but the following totalization agreements remove payment restrictions only for nationals of the two partner countries: Austria, Belgium, Denmark, Germany, Sweden, and Switzerland. ${ }^{8}$

\subsection{Similarities and differences in the characteristics of partner countries}

\subsubsection{Economic characteristics}

To understand totalization agreements' likely effects on the U.S. economy, it is important to consider the other participating countries' economic characteristics. Higherincome countries that are home to multinational firms are more likely to take advantage of a totalization agreement and send workers to an affiliate in the U.S. In addition, countries with more advanced economies, larger markets, and a more skilled workforce are more likely to be attractive places for American firms to open a branch. Hence, partner countries' economic characteristics are likely to be important determinants of the magnitude of a totalization agreement's impacts. Table 2 shows economic characteristics of the countries with which the U.S. has signed totalization agreements.

\footnotetext{
${ }^{7}$ Some countries allow for an extension beyond five years, which is typically no longer than two years and is decided on a case-by-case basis.

${ }^{8}$ Social Security Administration, https://www.ssa.gov/policy/docs/ssb/v78n4/v78n4p1.html. Furthermore, in the case of Belgium, the coverage and benefit provisions also apply only to nationals of the two countries.
} 
Table 2: Economic characteristics of countries with totalization agreements with the U.S.

\begin{tabular}{|c|c|c|c|c|c|c|}
\hline Country & GDP total ${ }^{\text {(a) }}$ & $\begin{array}{l}\text { GDP per } \\
\text { capita }^{(b)}\end{array}$ & $\begin{array}{c}\text { Population } \\
\text { (millions) }\end{array}$ & $\begin{array}{c}\text { FDI } \\
\text { (inflow) }\end{array}$ & $\begin{array}{c}\text { FDI } \\
\text { (outflow) } \\
\text { (d) }\end{array}$ & $\begin{array}{c}\text { FDI } \\
\text { (net) }^{(e)}\end{array}$ \\
\hline Australia & $1,257,101$ & 49,158 & 24.6 & 40,421 & 5,145 & $-34,482$ \\
\hline Austria & 393,265 & 43,057 & 8.8 & 14,184 & 14,178 & -5 \\
\hline Belgium & 477,694 & 39,537 & 11.38 & $-35,879$ & $-7,634$ & 28,245 \\
\hline Brazil & $2,075,703$ & 8,979 & 207.83 & 63,847 & 17,586 & $-46,260$ \\
\hline Canada & $1,697,690$ & 40,957 & 36.54 & 25,279 & 74,696 & 49,411 \\
\hline Chile & 247,553 & 13,665 & 18.47 & 5,318 & 4,700 & -618 \\
\hline Czech Rep. & 219,076 & 18,520 & 10.59 & 10,210 & 8,542 & $-1,667$ \\
\hline Denmark & 326,682 & 51,998 & 5.76 & 2,142 & 6,481 & 4,339 \\
\hline Finland & 238,061 & 41,625 & 5.51 & 12,659 & 12,908 & $-2,954$ \\
\hline France & $2,612,938$ & 35,150 & 66.87 & 43,017 & 51,821 & 12,650 \\
\hline Germany & $3,529,467$ & 40,604 & 82.66 & 75,803 & 124,858 & 49,054 \\
\hline Greece & 225,304 & 17,160 & 10.75 & 3,245 & 517.9875 & $-2,730$ \\
\hline Hungary & 139,610 & 12,976 & 9.79 & $-11,765$ & $-13,748$ & $-1,984$ \\
\hline Iceland & 16,003 & 64,808 & 0.34 & $-6,361$ & $-6,509$ & -148 \\
\hline Ireland & 325,729 & 62,651 & 4.81 & $-3,122$ & $-38,875$ & $-50,296$ \\
\hline Italy & $1,927,068$ & 29,221 & 60.54 & 8,313 & 11,820 & 3,498 \\
\hline Japan & $5,580,961$ & 34,834 & 126.79 & 18,557 & 157,976 & 139,419 \\
\hline Korea, Rep. & $1,223,132$ & 27,029 & 51.47 & 16,278 & 30,960 & 14,682 \\
\hline Luxembourg & 57,725 & 94,963 & 0.6 & 6,019 & 37,400 & 59,733 \\
\hline Netherlands & 839,431 & 44,059 & 17.13 & 5,462 & 4,042 & 43,577 \\
\hline Norway & 438,550 & 68,796 & 5.28 & 9,699 & 3,826 & $-1,421$ \\
\hline Poland & 546,162 & 12,596 & 37.97 & 9,108 & 657.935 & $-5,873$ \\
\hline Portugal & 217,138 & 19,348 & 10.3 & 1,290 & 6,616 & $-8,451$ \\
\hline Slovak Rep. & 98,277 & 15,975 & 5.44 & 5,382 & 3,652 & $-1,729$ \\
\hline Slovenia & 48,114 & 21,310 & 2.07 & 983 & 552.52 & -514 \\
\hline Spain & $1,371,985$ & 25,634 & 46.59 & 5,638 & 23,734 & 18,096 \\
\hline Sweden & 517,418 & 48,394 & 10.06 & 21,974 & 31,843 & 9,869 \\
\hline Switzerland & 594,879 & 73,003 & 8.45 & 62,057 & $-4,712$ & $-66,769$ \\
\hline U.K. & $2,561,494$ & 36,288 & 66.06 & 110,185 & 125,436 & 15,253 \\
\hline U.S. & $15,765,540$ & 54,460 & 325.15 & 322,450 & 344,617 & 27,193 \\
\hline Uruguay & 45,089 & 14,937 & 3.44 & 2,355 & 4,359 & 1,967 \\
\hline World & $72,890,111$ & 9,786 & $7,510.99$ & & & \\
\hline High income ${ }^{(f)}$ & $46,829,160$ & 38,482 & $1,204.43$ & & & \\
\hline
\end{tabular}

Notes: (a), (c)-(e) in millions of 2010 USD. (b) USD of 2010. Source: World Development Indicators, World Bank. All data is for 2017. (f) Includes all countries considered as "high income" per the World Bank's definition of having a high gross national income per capita above $\$ 12,376$ in 2019. 
For the most part, these countries are developed, with highly-educated populations and high incomes. Save for Brazil, all countries classify as "High Income" per the definition of the World Bank. ${ }^{9}$ Most totalization agreements have been signed with countries in Europe and East Asia, with GDP per capita of a level close to, or above the average GDP per capita of high-income economies (which in 2017 was around $\$ 42,000$ per person, or $\$ 38,482$ in 2010 USD). The list of countries includes some small nations with very high per capita incomes, such as Iceland, Luxembourg, Norway, and Switzerland, as well as some large economies with incomes around the US $\$ 40,000$ mark, such as France, Germany, and Japan.

More recently, the U.S. has signed totalization agreements with relatively lower income countries (per capita income levels between US\$10,000 and around US\$20,000), mostly in Eastern Europe and Latin America. Among them are several that until recently were considered "high middle income" by the World Bank, including Chile, Uruguay, Slovenia, and the Slovak Republic. These tend to be smaller countries in terms of population and total GDP, so it is likely that the impact of these agreements upon the American economy has been smaller. Among these countries, the largest in terms of GDP are Poland, with a GDP of around \$546 billion, and Chile, with a GDP of \$248 billion (all in 2010 USD).

Brazil, with which the U.S. signed a totalization agreement in 2018 , is the only country in the list with a GDP per capita below the world average of US $\$ 9,786$. The economic impacts of agreements with countries like Brazil may be different because of the different economic development level. The effects may be important, too, given the

\footnotetext{
${ }^{9}$ The World Bank defines a country as "high income" if its gross national income per capita is above US $\$ 12,376$.
} 
size of the Brazilian economy, with a population of more than 207 million and a GDP of USD $\$ 2.1$ trillion. $^{10}$

The countries with which the U.S. has signed totalization agreements also vary in terms of openness, and the levels of FDI inflows and outflows. Though no partner country has a level of FDI flows as high as the U.S. (more than US $\$ 300$ billion both inward and outward), some do have high levels in both directions (Germany has about US $\$ 83$ billion inflow and US $\$ 137$ billion outflow). Brazil had very high levels of inward FDI (US $\$ 70$ billion) in 2017 but not as much outward (US $\$ 19$ billion). Japan had lower levels of incoming FDI (US\$19 billion) and high levels of outgoing FDI (US\$173 billion). Other partner countries have much lower levels of FDI flows, such as Chile (US $\$ 6$ billion outflow and US\$6.7 billion inflows in 2017).

\subsubsection{Characteristics of the social security systems}

The totalization agreements' effects may be affected not only by the content of the agreement and the general economic characteristics of the partner country, but also by the characteristics of the nations' respective social security systems. This follows from the fact that totalization agreements include rules about which social security system to participate in. Hence, a totalization agreement's impacts likely will depend on the characteristics of the partner country's social security system.

If a partner country has a social security system with high required contributions, then the effect of reducing the double taxation for U.S. firms sending American workers to the partner country likely will be relatively high. On the other hand, if a partner country has relatively low contributions, then the likely impacts will be low.

\footnotetext{
${ }^{10}$ Due to the recency of this agreement, there are no data to evaluate its effects.
} 
Analyzing a subset of partner countries' social security systems, we found similarities in some aspects of the systems directly relevant for the analysis of totalization agreements. Similarities include the following: 1) There is a required taxation of labor income above a certain threshold (in some countries that threshold is zero); 2) there is a fixed social security tax rate above that threshold; and, 3) a threshold above which labor income is not taxed. Most variation in the payments into the system can be analyzed in this manner. Table 3 describes the social security systems along these dimensions among the selected subset of partner countries.

In terms of the rates paid, differences are moderate. Social security contribution rates to pay for old age, disability, and survivor benefits are typically in the $12 \%$ to $19 \%$ range, with the exception of Brazil, where rates are substantially higher $(28 \%)$. However, there is stronger variation in terms of the upper threshold amount, the "wage ceiling," which affects the effective tax rate high earners actually pay. Japan has a relatively high wage ceiling, with social security contributions capped at $620,000 \mathrm{JPY}$ per month, which means that only annual earnings above 40.7 million JPY (around US $\$ 382,000$ ) do not incur additional social security taxation.

Relatively less developed countries have lower values of the threshold. In Chile, incomes beyond a level of 908 Unidades de Fomento (which in 2017 corresponded to about $\$ 36,000$ ) pay no social security contributions. This likely responds to the fact that the earnings distribution in that country is to the left of the income distribution in developed countries. This has important implications for the analysis of its totalization agreement, as employees of American firms who would be deployed to Chile under a situation of no totalization agreements would be more modestly affected by double taxation because a large fraction of their earnings would be above the threshold hence, nontaxable. 
Also likely to be important are the characteristics of social security systems in terms of benefits paid and qualifying requirements. Here, what matters are the characteristics of the sending country's social security system. Assume a country has relatively strong requirements in terms of the number of quarters/years an employee must work to qualify for retirement benefits. In this case, fewer people will want to take on an assignment abroad absent a totalization agreement, as more people may otherwise fail to meet the threshold. On the other hand, if a country requires few quarters, there will be many more workers who will have already satisfied the quarter requirement, and therefore are less likely to be concerned that failing to contribute in a given year to their home country will affect their entitlement.

Table 3: Characteristics of social security system contributions in selected countries

\begin{tabular}{lcr}
\hline Country & $\begin{array}{c}\text { Tax Rate } \\
\text { Overall }\end{array}$ & Wage Ceiling \\
\hline Brazil & $28 \%^{\mathrm{a}}$ & \\
\hline Chile & $13.54 \%^{\mathrm{b}^{*}}$ & $\sim \$ 36,000^{\mathrm{t}}$ \\
\hline Germany & $18.7 \%$ & $\$ 86,580$ \\
\hline Japan & $18.3 \%{ }^{\mathrm{c}}$ & $\sim \$ 382,164$ \\
\hline USA & $12.4 \%$ & $\$ 132,900$ \\
\hline
\end{tabular}

Notes: *Tax rates shown are those paid for old-age, disability, and survivor benefits. Sources: ILO (2017) and SSA (2018b, 2018c, 2019). ' 'Lower rates allowed for small businesses and selfemployed. Rural sector excepted. ${ }^{\mathrm{b}}$ This is based on the Mandatory individual account program started in 1980. Rate amounts to $12.82 \%$ total under the DB program (source: SSA 2018c, Table 4). The maximum annual earnings used to calculate contributions are 908.4 UFs (Unidad de Fomento; up to $\sim \$ 36,000$ annually as of 2017 . ${ }^{\circ}$ Used to be $17,8 \%$ (8.9\% employer and employee).

Likewise, the level of benefits can be important. The more generous the retirement benefits are in a country, the more likely it is that workers there will be concerned about meeting the requirement for receiving benefits (that is, the more they will require as compensation). Hence, the higher the benefits in a sending country's 
social security system, the more impact a totalization agreement will have. Table 4 describes the characteristics of the social security systems' eligibility requirements and shows the average net pension replacement rates, including income from social security retirement benefits.

Table 4: Benefit characteristics of social security systems

\begin{tabular}{|c|c|c|}
\hline Country & $\begin{array}{l}\text { Number of years of contribution or employment } \\
\text { required to qualify for retirement benefits * }\end{array}$ & $\begin{array}{l}\text { Net Pension } \\
\text { Replacement } \\
\text { Rates }^{* *} \\
\end{array}$ \\
\hline Australia & N.A. & 42.6 \\
\hline Austria & 15 years & 91.8 \\
\hline Belgium & $\begin{array}{l}66.7 \% \text { of a full career (based on } 208 \text { days for } 45 \\
\text { years) to qualify for the Guaranteed minimum pension }\end{array}$ & 66.1 \\
\hline Brazil & 15 years & 76.4 \\
\hline Canada & 1 year & 53.4 \\
\hline Chile & $\begin{array}{l}10 \text { years (and contribute within two years prior to } \\
\text { reaching retirement age). } 20 \text { years to qualify for } \\
\text { minimum benefit under new program }{ }^{c}\end{array}$ & 40.1 \\
\hline Czech Republic & N.A. & 60 \\
\hline Denmark & N.A. & 80.2 \\
\hline Finland & $\begin{array}{l}3 \text { years of residence (full pension if reside for } 80 \% \text { of } \\
\text { period from age } 16 \text { to } 64 \text { ) b }\end{array}$ & 65 \\
\hline France & $\begin{array}{l}0.25 \text { years (between } 163 \text { and } 172 \text { quarters for full } \\
\text { pension }\end{array}$ & 74.5 \\
\hline Germany & 5 years & 50.5 \\
\hline Greece & 15 years & 53.7 \\
\hline Hungary & 20 years & 89.6 \\
\hline Iceland & N.A. (40 years for full pension private sector) & 75.7 \\
\hline Ireland & 520 weeks (less than 10 years) & 42.3 \\
\hline Italy & 15 years & 93.2 \\
\hline Japan & 10 years (40 years for full pension) & 40 \\
\hline Luxembourg & 20 years for minimum guaranteed pension & 88.4 \\
\hline Netherlands & N.A. & 100.6 \\
\hline Norway & 3 years of residence (40 years for full) ${ }^{b}$ & 48.8 \\
\hline Poland & 20 years for men and 15 years for women & 38.6 \\
\hline Portugal & 15 years & 94.9 \\
\hline Slovak Republic & 15 years & 83.8 \\
\hline Slovenia & 20 years & 56.7 \\
\hline South Korea & 20 years & 45.1 \\
\hline Spain & 15 years with at least 2 years in the last 15 years & 81.8 \\
\hline Sweden & 3 years & 54.9 \\
\hline Switzerland & N.A. ${ }^{a}$ & 44.9 \\
\hline United Kingdom & 1 year (30 years for full) & 29 \\
\hline United States & 40 quarters & 44.8 \\
\hline Uruguay & 15 years at age 70 (more to retire earlier) & Not available \\
\hline
\end{tabular}


Notes: *Sources Table B.9 of ILO (2017), Tables 4 of SSA (2018b, 2018c, 2019) ** Pension Income as a \% of preretirement income, defined as the individual net pension entitlement divided by net preretirement earnings, taking into account personal income taxes and social security contributions paid by workers and pensioners. Note that it includes pension sources beyond Social Security. Source: OECD Data (data.oecd.org). ${ }^{a}$ Benefit is paid as $6.8 \%$ of the total balance in personal account at the time of retirement. ${ }^{b}$ Resident requirement. ${ }^{c}$ The rules described here are for 1980.

\section{Analysis of macroeconomic flows}

\subsection{Data}

The implementation of totalization agreements may impact macroeconomic outcomes of the participating countries, such as flows of capital and investment between them. We used the time series from the Bureau of Economic Analysis (BEA) about FDI flows and activities of U.S. multinational firms' foreign affiliates and foreign multinational firms' U.S. affiliates. For all countries for which data are available, we conducted an event study analysis around the time the treaties were put into place to characterize the evolution of bilateral flows. This provides suggestive evidence of how the agreements may have impacted these flows.

Additionally, we measured how treaties affected bilateral employment flows and used these data to quantify the model in the next section. For this, we constructed the evolution of employment flows specifically for workers covered by totalization agreements by leveraging the following additional data sources. To generate descriptive statistics of the flows of American workers who have benefited from totalization agreements over time, we used data from the U.S. Certificates of Coverage issued to Americans working abroad. Also included in the descriptive analysis were data from foreign Certificates of Coverage, available for a subset of years and countries, issued to workers moving to the U.S. 
We complemented this information with tax-filing data from the Internal Revenue Service (IRS). We used the number of foreign-earned income credit exclusion tax forms filed by American taxpayers to analyze the impact of totalization agreements on the flow of U.S. workers going to work abroad. The IRS reports these numbers for 1987 and every five years between 1991 and $2011 .{ }^{11}$ For the countries with available data, we measured how treaties' enactments affected these flows, conducting event studies around the time the agreements were put in place. For an analysis of flows of foreign workers coming to work in the U.S., we used data on certain types of nonimmigrant visas, ${ }^{12}$ by nationality, issued by the U.S. Department of State since 1997. Though not everyone coming to the U.S. with a certain type of visa necessarily is covered by a totalization agreement, this information is a good proxy. In particular, inflow changes from partner countries of individuals with the relevant visas are likely to be strongly correlated with changes in the number of individuals covered by an agreement.

As an additional component of the descriptive evidence, we report statistics on the benefits paid over time to workers covered by totalization agreements. This is especially informative about past flows of workers for countries with the oldest bilateral agreements, and serves as a quantitative check for the model as explained in the next section.

\subsection{Magnitude of totalization agreements}

To benefit from the coverage provisions of a totalization agreement, workers must file a certificate of coverage with the respective authorities. These certificates

\footnotetext{
${ }^{11}$ https://www.irs.gov/statistics/soi-tax-stats-individual-foreign-earned-income-foreign-tax-credit

${ }^{12}$ In particular, we consider visa categories that — like the L, $\mathrm{H}$ and $\mathrm{E}$ categories - are the most likely ones to be granted to temporary workers who might benefit from the totalization agreements.
} 
contain some basic information, such as the worker's name and Social Security Number (or foreign equivalent), information about the employer, and begin and end dates of the foreign assignment. The SSA provided us with information about U.S. certificates of coverage for the period 2009 to 2018 and foreign certificates for 2009 to 2015 . The data include, for each anonymized certificate, the year it was received, the partner country, and the begin and end date of the assignment. ${ }^{13}$ Table 5 reports data on the number of certificates submitted by American workers for assignments abroad and the number of certificates for foreign workers on assignment in the U.S., for the years where the data are most reliable.

${ }^{13}$ The data are incomplete, however. For some certificates, begin and end dates are blank, and for some country/year combinations, only a subset of certificates have been entered, or none at all. This is especially true for foreign-issued certificates, for which we only have a small subsample. We received a separate file of counts of foreign certificates, but these are also tentative, and most reliable for 2009, 2010, and 2012, which we are reporting in Table 5. In general, the tables and figures based on the certificate data should be viewed as illustrations of patterns rather than as definitive numbers. 
Table 5: Number of certificates by country

\begin{tabular}{lrrrr}
\hline \multirow{2}{*}{ Country } & \multicolumn{2}{c}{$\begin{array}{c}\text { U.S. certificates } \\
(\mathbf{2 0 0 9 - 2 0 1 8 )}\end{array}$} & \multicolumn{2}{c}{$\begin{array}{c}\text { Foreign certificates } \\
(\mathbf{2 0 0 9 , 2 0 1 0 , 2 0 1 2 )}\end{array}$} \\
\cline { 2 - 5 } & Total & Avg per year & Total & Avg per year \\
\hline Australia & 13,403 & 1,340 & $\mathrm{n} / \mathrm{a}$ & $\mathrm{n} / \mathrm{a}$ \\
Austria & 1,172 & 117 & 271 & 90 \\
Belgium & 7,706 & 771 & 1,820 & 607 \\
Brazil & 99 & - & - & - \\
Canada & 33,927 & 3,393 & 7,323 & 2,441 \\
Chile & 2,041 & 204 & $\mathrm{n} / \mathrm{a}$ & $\mathrm{n} / \mathrm{a}$ \\
Czech Republic & 1,504 & 151 & 120 & 60 \\
Denmark & 962 & 96 & 972 & 324 \\
Finland & 869 & 87 & 1,040 & 347 \\
France & 18,484 & 1,848 & $\mathrm{n} / \mathrm{a}$ & $\mathrm{n} / \mathrm{a}$ \\
Germany & 20,440 & 2,044 & 6,976 & 2,325 \\
Greece & 891 & 89 & $\mathrm{n} / \mathrm{a}$ & $\mathrm{n} / \mathrm{a}$ \\
Hungary & 476 & 238 & - & - \\
Ireland & 3,852 & 385 & 2,379 & 793 \\
Italy & 7,555 & 756 & 333 & 111 \\
Japan & 10,413 & 1,041 & 20,743 & 6,914 \\
South Korea & 1,368 & 342 & 1,293 & 431 \\
Luxembourg & 785 & 79 & 582 & 194 \\
Netherlands & 6,242 & 624 & 4,431 & 1,477 \\
Norway & 2,873 & 287 & 1,141 & 380 \\
Poland & 1,384 & 145 & 184 & 85 \\
Portugal & 780 & 78 & $\mathrm{n} / \mathrm{a}$ & $\mathrm{n} / \mathrm{a}$ \\
Slovakia & 107 & 27 & - & - \\
Spain & 7,610 & 761 & 1,242 & 414 \\
Sweden & 2,388 & 239 & 573 & 191 \\
Switzerland & 10,760 & 1,076 & $\mathrm{n} / \mathrm{a}$ & $\mathrm{n} / \mathrm{a}$ \\
United Kingdom & 41,134 & 4,113 & 6,203 & 2,068 \\
\hline Total & 199,227 & 19,923 & 57,626 & 19,252 \\
\hline Note: Data & & & & \\
\hline
\end{tabular}

Note: Data are incomplete and should be viewed as roughly indicative of relative patterns. Averages per year only include years with available data and exclude the first (calendar) year in which an agreement was in effect. n/a: Not available; - : agreement not in effect yet. Source: SSA

With the caveat that these data (in particular the foreign data) are far from complete, and that the years covered are not the same, this table suggests that the numbers of U.S. and foreign certificates per year are of similar magnitude overall, 
although this does not hold on a country by country basis. Furthermore, the number of workers under totalization varies greatly by country. This may be due to the size of the country, characteristics of the country's workforce and productive structure, and characteristics of the country's social security system. Our model in Section 4 takes such characteristics into account.

Figure 1 shows the number of U.S. coverage certificates issued over time. The number of certificates has increased over time. Data for the last available year are incomplete, with a smaller set of countries, which explains the apparent drop. The timing of the certificates does not indicate the start of a foreign assignment, only when the certificate was issued. The number of certificates active during at least part of any given year will be higher (depending on the average duration of the assignments as presented below), because this includes certificates that have been issued in previous years that pertain to multi-year assignments, and the cumulative number of certificates ever issued is much higher still.

Figure 2 shows the duration distribution of the assignments listed on the certificates of coverage issued in the U.S. and abroad. From these figures, we see the vast majority of assignments for which a certificate is issued are for five years or less. This is, of course, expected given that only under rare exceptions will a totalization agreement allow exception from the territoriality rule on stays longer than five years. This indicates that for most of these assignments, the country of greater economic attachment will be the worker's own country. In our data, a handful of assignments have a duration of more than 10 years. These have been excluded from the graphs, but this does not affect the conclusion. 
Figure 1: Number of U.S. certificates of coverage for totalization agreements (2009-2018)

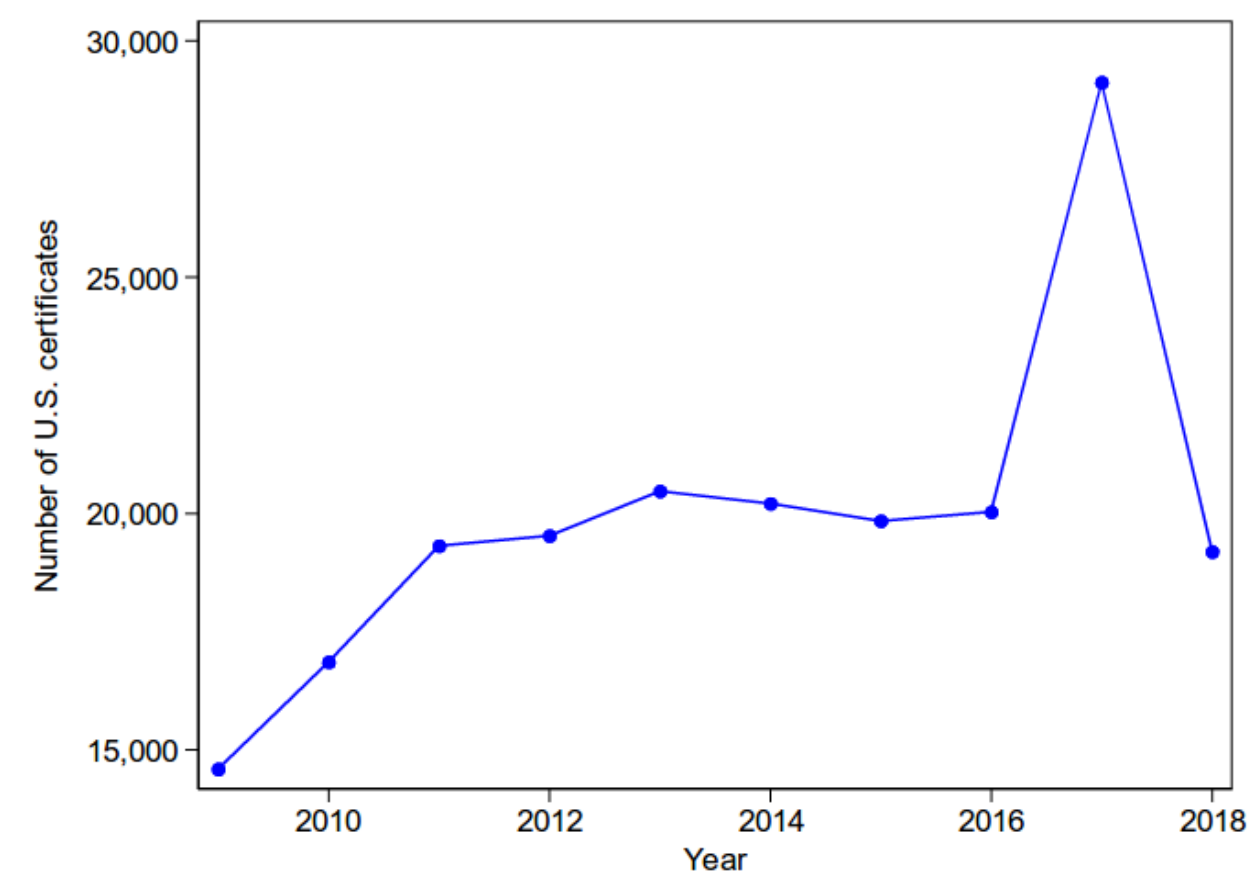

Note: Data for the last year are available for only a subset of countries, so the apparent drop does not reflect the actual trend. Source: SSA

Furthermore, we observe a clear pattern of bunching at whole years. However, there still are many assignments, especially shorter assignments, with durations that are not whole years. It is also noteworthy that there are spikes near zero. ${ }^{14}$

${ }^{14}$ Precise zeros and negative durations have been excluded, which are likely coding errors. We expect that very short assignments (say, up to three months) in a foreign country would simply be business visits and in many cases would not require a formal certificate of coverage, so part of these may also be coding errors, but we did not exclude these because they may be valid. From the data available to us, we could not deduce whether these were temporary assignments to a foreign country by the home country employer or a foreign employer's temporary jobs in the foreign country. 
Figure 2: Duration distribution of the assignments

U.S. certificates (2009 to 2018)

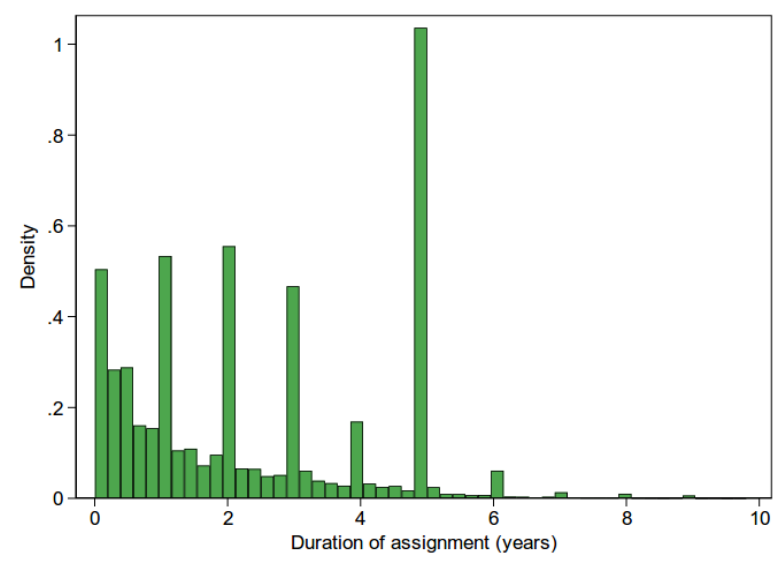

Foreign certificates (2009 to 2015)

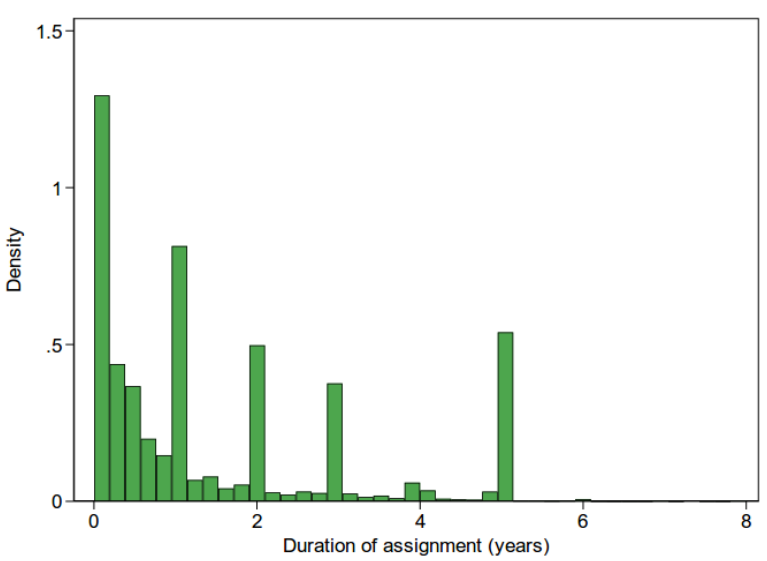

Source: $S S A$

\subsection{Characteristics of affected individuals}

The SSA provided us with a data set about the earnings of individuals contributing to the U.S. Social Security system under a totalization agreement for the years 2009 to 2017 . There are two types of earnings concepts: "OASDI earnings," which are subject to Social Security taxation under the Old-Age, Survivors, and Disability Insurance (OASDI) program, and "Medicare earnings," which are subject to Medicare taxation. Not all jobs are covered by Social Security and, thus, subject to Social Security taxation. This applies especially to government jobs. There is no such exclusion for Medicare. Furthermore, earnings are capped at the Social Security maximum for Social Security taxation. This maximum was $\$ 106,800$ in 2009 and increased to $\$ 127,200$ in $2017 .{ }^{15}$ In this section's graphs and tables, we converted all amounts to 2015 dollars using the consumer price index (CPI), which means the Social Security maximum was $\$ 117,991$ in 2015 dollars (real terms) in 2009 and $\$ 122,995$ in

\footnotetext{
${ }^{15}$ https://www.ssa.gov/oact/COLA/cbb.html
} 
2017. Both OASDI earnings and Medicare earnings reported here include earnings as an employee as well as self-employment earnings, if any. ${ }^{16}$

Figure 3 shows, by year, the average and median earnings of U.S. workers who filed certificates of coverage under a totalization agreement. Earnings of such workers were high relative to the average earnings of American workers. ${ }^{17}$ The median OASDI earnings were at or near the Social Security maximum in all these years, meaning that about half the affected workers earned more than the Social Security maximum. The mean was not much lower, which implies there is not a substantial fraction of affected workers whose earnings are far below the Social Security maximum. Further supporting this are the much higher average and median Medicare earnings. This suggests individuals who submitted certificates of coverage were mostly managers and professionals. We used this assumption in the development of our theoretical model in Section 4 .

Figure 4 shows the average real earnings over these years by country of destination. Despite overall average OASDI earnings being closer to the Social Security maximum, workers sent to some smaller countries, such as Greece and Slovakia, have lower average earnings. The average Medicare earnings vary widely across countries, but are not always consistent with the host country's average income level. We conjecture that this may be partly due to outliers and the relatively small numbers of workers for some countries.

\footnotetext{
${ }^{16}$ The SSA obtained these data from the IRS, which computed them from W-2 forms for employment earnings and Schedule SE for self-employment earnings.

17 The national average wage index for 2017 is $\$ 50,321.89$ (Source: SSA, https://www.ssa.gov/oact/cola/AWI.html)
} 
Figure 3: Annual earnings of individuals under totalization agreements by year

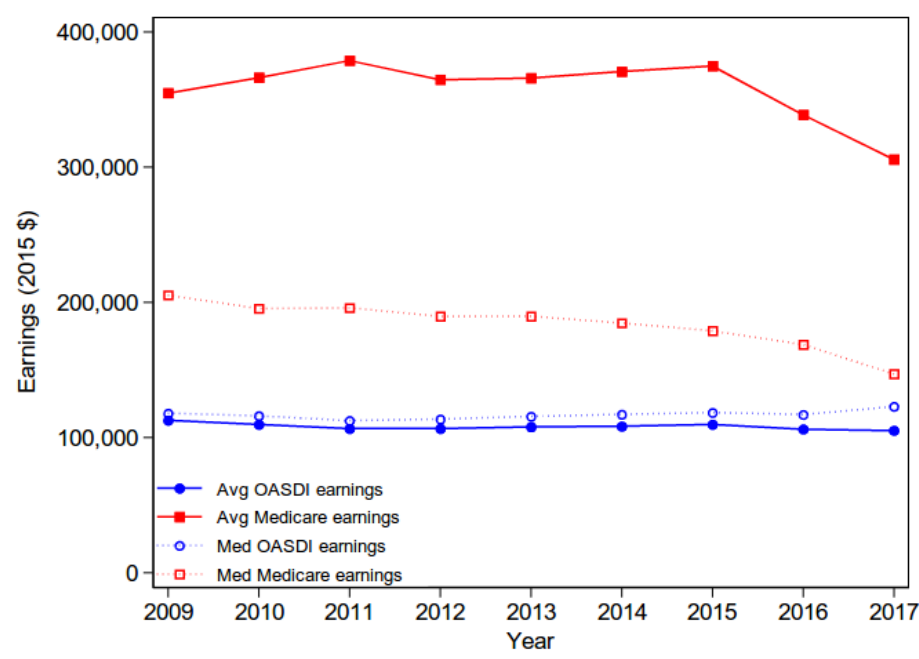

Source: SSA

Figure 4: Annual earnings of U.S. individuals under totalization agreements by country of destination

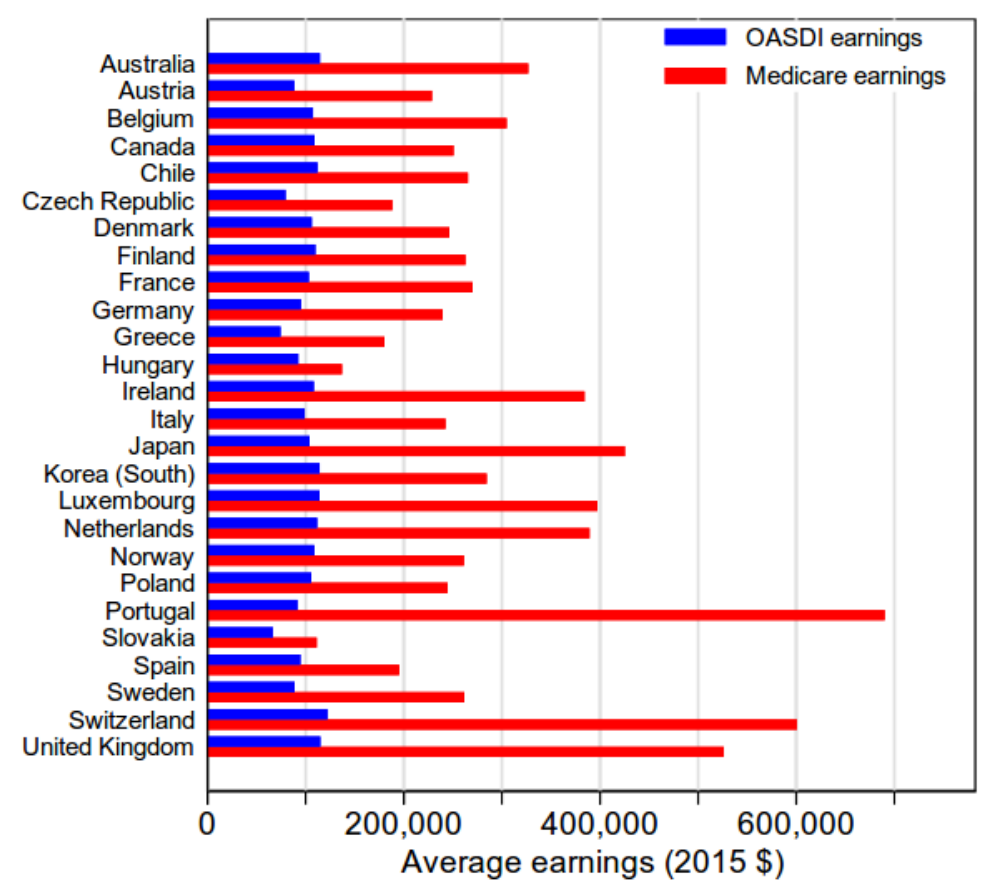

Source: SSA 
The SSA's Annual Statistical Supplement $(2018)^{18}$ provides information about the number of individuals receiving Social Security benefits in the U.S. who have been affected by totalization agreements. These are workers, either Americans or U.S. residents who worked in a foreign country for a period in their lives, whose country of greater economic attachment was the U.S. and are now receiving benefits. Although not everyone receiving totalized benefits has filed a certificate of coverage, the overall trends should be similar. ${ }^{19}$

Figure 5 shows the total number of beneficiaries by year since 1983. Unsurprisingly given the increased number of agreements and the gradual aging of workers into retirement, the number of beneficiaries has been increasing, from close to zero in 1983 to 237,000 in 2018 . According to the same Annual Supplement, the total number of Social Security benefit recipients was about 63 million in 2018, so about $0.4 \%$ of recipients were affected by totalization agreements in 2018 .

Figure 5: Number of totalization beneficiaries by year

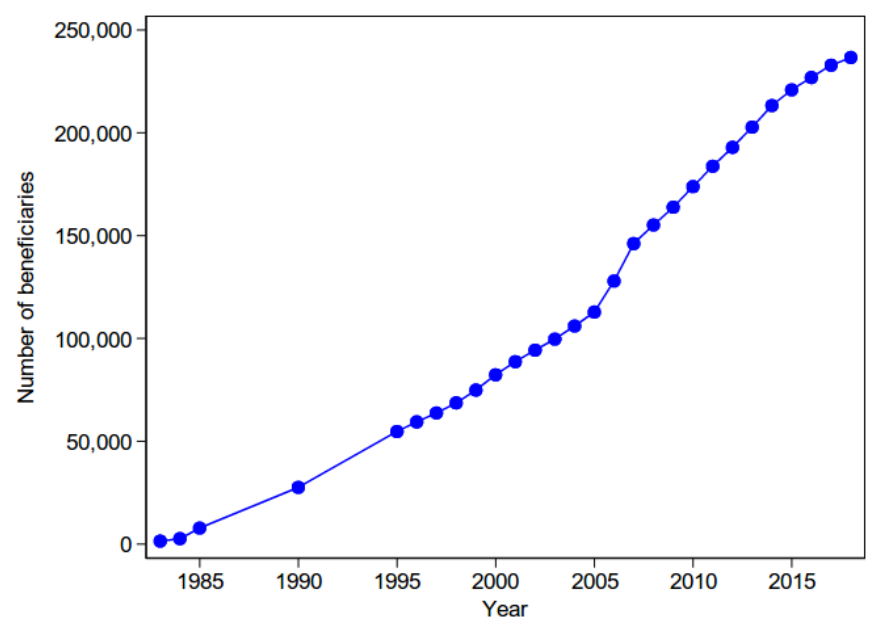

Source: $S S A$

\footnotetext{
${ }^{18}$ Table 5.M1, available from https://www.ssa.gov/policy/docs/statcomps/supplement/index.html

${ }^{19}$ Examples of this are people who worked in the U.S. before the agreements went into force or those hired in the U.S. locally who may later receive a totalized benefit but were never issued a certificate of coverage.
} 
Table 6 shows the average number of U.S. beneficiaries per year by host country for the period 1999 to 2018 . The averages for countries with totalization agreements more recent than 1999 correspond to the years when the agreements were in place. As expected, the annual number of beneficiaries by country is strongly correlated with the number of certificates (Table 5) and with the elapsed time since the agreement was introduced (Table 1).

Table 6: Average annual number of U.S. beneficiaries and monthly benefits (in 2015 USD) by country (1999-2018)

\begin{tabular}{lcr}
\hline Country & $\begin{array}{c}\text { Number } \\
\text { of years }\end{array}$ & $\begin{array}{r}\text { Average number of } \\
\text { beneficiaries }\end{array}$ \\
Australia & 16 & 2,743 \\
Austria & 20 & 1,281 \\
Belgium & 20 & 812 \\
Canada & 20 & 47,175 \\
Chile & 17 & 168 \\
Czech Republic & 10 & 92 \\
Denmark & 10 & 535 \\
Finland & 20 & 311 \\
France & 20 & 4,961 \\
Germany & 20 & 19,226 \\
Greece & 20 & 3,697 \\
Hungary & 2 & 30 \\
Ireland & 20 & 2,204 \\
Italy & 20 & 9,024 \\
Japan & 13 & 39,690 \\
Luxembourg & 20 & 79 \\
Netherlands & 20 & 2,289 \\
Norway & 20 & 3,570 \\
Poland & 10 & 8,895 \\
Portugal & 20 & 2,381 \\
Slovakia & 5 & 19 \\
South Korea & 15 & 1,950 \\
Spain & 20 & 2,814 \\
Sweden & 20 & 2,622 \\
Switzerland & 20 & 3,951 \\
United Kingdom & 20 & 1531 \\
\hline Total & 20 & \\
\hline & & 19 \\
\hline
\end{tabular}

Note. Number of years varies across countries because some totalization agreements were enacted after 1999. Source: SSA 
Totalized benefits were less than $\$ 240$ in 2018 , whereas the average benefits of all recipients were $\$ 1,267$ (in 2015 dollars). Totalized benefits are prorated to be proportional to the time that the worker paid into the U.S. Social Security system. ${ }^{20}$

\subsection{Employers listed on U.S. certificates}

To get an impression of what kinds of employers send their employees on foreign assignments, SSA provided us with lists of employers named on U.S. certificates of coverage submitted from 2009 through 2018. These were not linked to individual records, but we still could study the number of certificates per employer from these lists. There are 10,000 to 20,000 records per year, with 148,431 records in total.

A challenge with analyzing data in which the identifiers are text fields (e.g., name, address) is that these identifiers are often inconsistently spelled. For example, we might see My Company as well as My Company, Inc. and My Company Inc with no period for the abbreviation and no comma. We performed a small amount of standardization but did not try to obtain the "best" or "smallest" set of company names. Specifically, we transformed all employer names to lowercase; removed all periods and commas; put spaces around ampersands; removed the words inc, incorporated, Ilc, Ilp, Itd, corporation (but not corporate), and company; replaced self employed with selfemployed; removed an initial word the, removed all leading and trailing spaces, and

\footnotetext{
20 The pro rata factor is the number of quarters the individual worked under a totalization agreement as a fraction of the individual's total number of covered quarters (truncated at the 35 years used for AIME computations). It is worth noting that totalized benefits may only correspond to workers who are not fully insured for social security benefits due to their accumulated quarters of coverage in the U.S. A person with more than 39 quarters of U.S. coverage would be fully insured for benefits, and would not receive totalization benefits (unless they are using foreign periods of coverage for purposes of meeting the recency-of-work requirement for entitlement to disability benefits).
} 
condensed all consecutive internal spaces to single spaces. These particular choices were driven by iteratively listing the 100 most-commonly mentioned employers, then screening out duplicates. We did not combine My Company, My Company U.S., My Company International, and similar distinctions. We saw such designators in the lists, as well as other indicators of multiple branches of the same company.

After this standardization, we ended up with 18,148 employers - including selfemployed, which occurs 2,600 times. The mean number of records per employer is slightly more than eight, but the distribution of number of records per employer is highly skewed: More than half of the employers have only one record, and the 75th percentile is three records. Slightly more than $1 \%$ of employers have more than 100 records. The top 100 employers with the most records are dominated by large multinational firms: energy, financial companies, manufacturing (including automobiles and pharmaceuticals), business consulting, construction, and software, but it also contains some other types of companies (some lesser known) and organizations of Christian missionaries and teachers.

\subsection{Event study analysis}

For each country, we analyzed the flows around the time of enactment of the totalization agreement. The longest time series available corresponds to foreign direct investments abroad and in the U.S. The FDI flow into the U.S. by source country before and after the date on which each totalization agreement became effective is shown in Figure 6 . The left panel is the 10-country group with the highest levels of FDI in the U.S., and the right panel shows the other countries. Similarly, Figure 7 shows the flow of direct investment abroad by U.S. firms, with the same country grouping as in Figure 6 .

For most countries in both groups in Figure 6, investment in foreign firms' U.S. affiliates increases over time. However, there is some variation in the growth patterns 
around the time of an agreement's implementation $(t=0)$. For some countries - among them, the Netherlands, France, Luxemburg, South Korea, Sweden, and Belgium — the growth rate seems to have increased after the totalization agreement became effective, while growth of inward FDI from other countries — such as Japan and the U.K. seems to have continued at the same pace as before the agreement. The inward FDI level from most countries in the group on the right remains very low for many years after the implementation of the agreements, or even for the full sample, such as the cases of Portugal, Greece, and Chile.

Figure 7 shows that outward FDI of U.S. firms mostly grows over the sample period for most host countries. There do not seem to be sharp growth rate changes in outward FDI at the time of implementation of the agreements, except for a few host countries such as the U.K., the Netherlands, and France, which show a slight uptake on FDI growth after $t=0$. 
Figure 6: Inward U.S. FDI flows - direct investment in U.S. affiliates of foreign firms (Millions of 2010 USD)
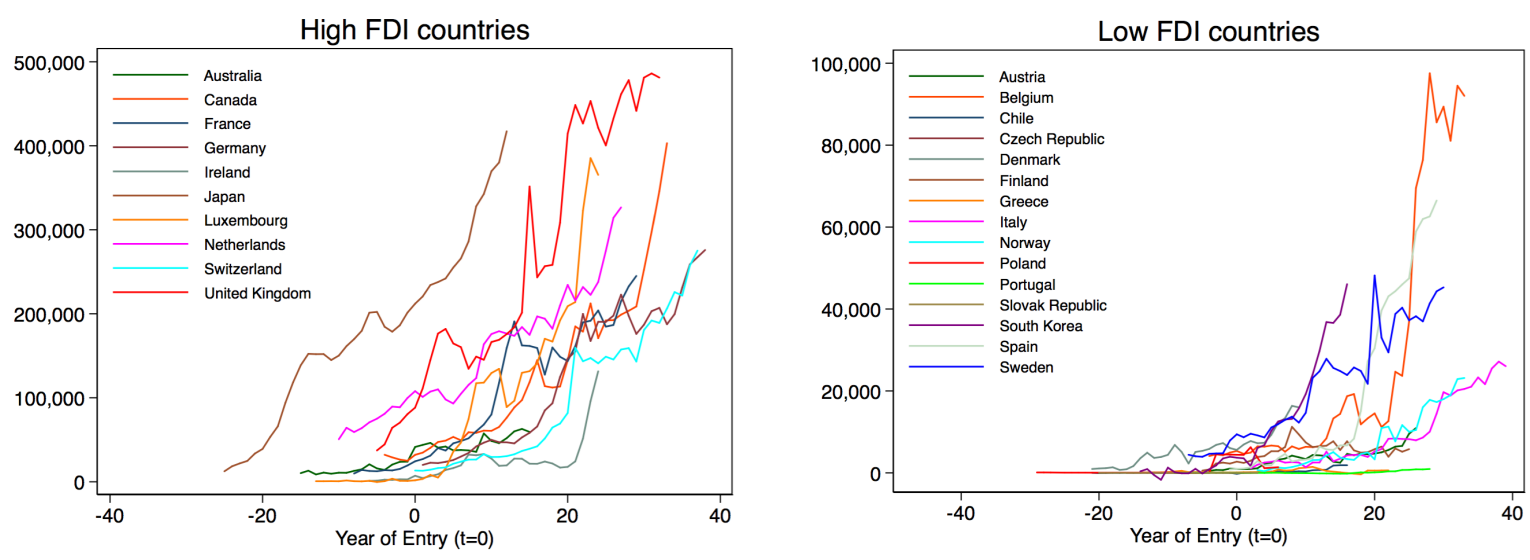

Source: BEA

Figure 7: Outward U.S. FDI flows - direct investment in foreign affiliates of U.S. firms (Millions of 2010 USD)
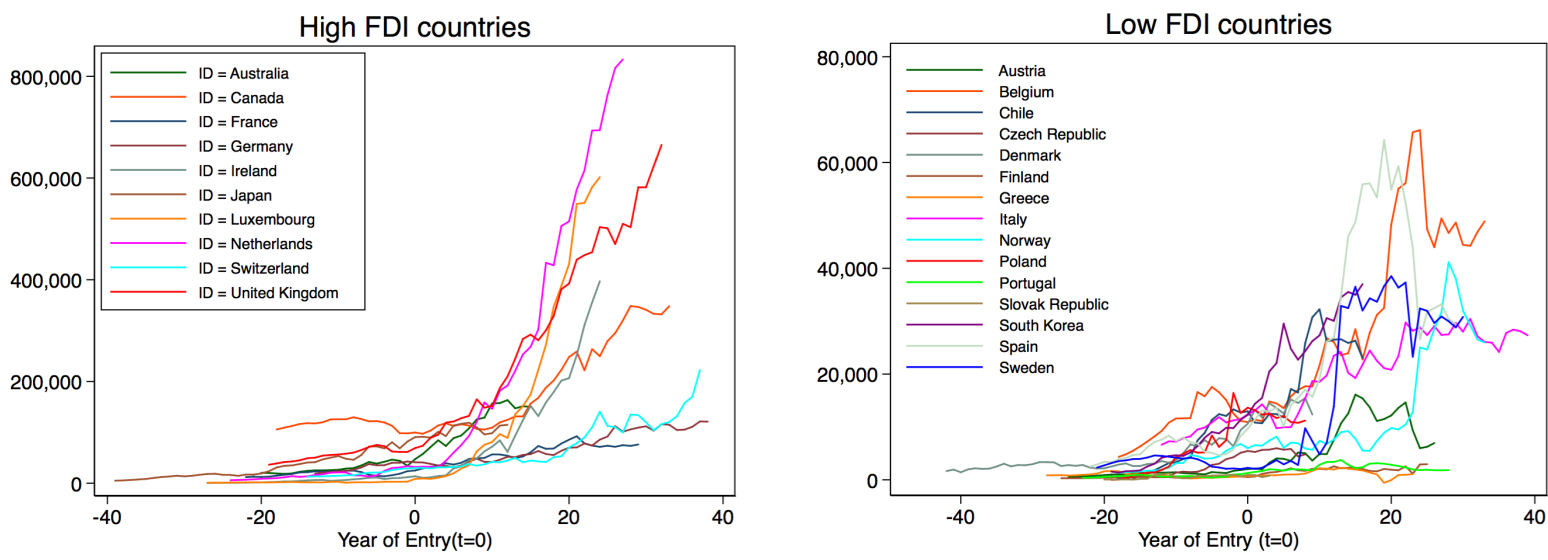

Source: $B E A$ 
To analyze totalization agreements' possible effects on the activities of multinational firms who benefit from them, we look at the evolution of total assets and employment around the time of treaty implementation. Figures 9 and 10 report, for each country and activity, two time series corresponding to different groups of firms. The time series available for the earliest years, in dotted lines with and without markers, correspond to activities of foreign multinational firms' U.S. affiliates (1997 through 2006) and affiliates of American multinationals abroad (1997 through 2008) not in the banking sector. The most recent time series, in solid lines with and without markers, correspond to multinational affiliates in all sectors. Due to data limitations, we only report these for a series of countries with relatively recent totalization agreements: Australia, Chile, Japan, and Poland.

For countries with available data encompassing years before and after the adoption of the agreements, Figure 8 shows examples of event studies corresponding to the total assets of affiliates of foreign firms in the U.S. and of American firms abroad. The evolution of total assets displays a similar pattern in all four countries. For both affiliates of American firms abroad and foreign firms in the U.S., total assets increase around the time of agreement implementation, except in Poland where the asset levels of Polish affiliates in America remain low throughout the sample period. In the case of U.S. affiliates in Poland, the year of implementation of the totalization agreement coincides with the change in time series, and therefore the trend cannot be assessed around this time. There seems to be no clear break in trend around the time of the totalization agreement enactment for these countries. 
Figure 8: Total assets of multinational firms around the time of totalization agreements effective dates

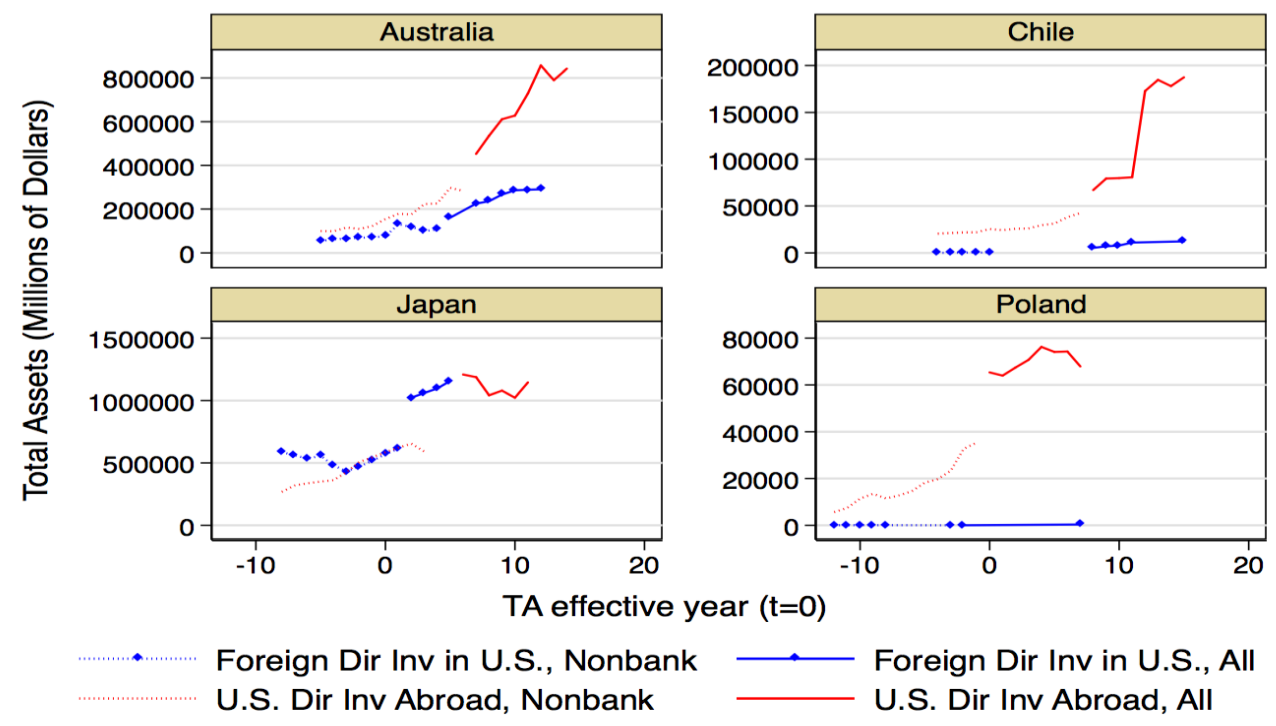

Source: $B E A$

Figure 9 shows the same countries' event studies presenting the total employment of affiliates of foreign firms in the U.S. and of American firms abroad. Not all countries show the same pattern. American multinationals' affiliates in Chile and Poland seem to have increased total employment over the sample period, although no clear trend break is observable around the time of agreement implementation. The employment of U.S. affiliates of Chilean and Polish firms is negligible.

There is no clear trend in employment for Australian affiliates in the U.S. nor for American affiliates in Australia. For Japan, it appears employment trends changed around the time of the totalization agreement with the U.S., but we cannot assume the agreement was the cause. It certainly does not seem totalization agreements increased the employment levels of American affiliates in Japan, Australia, or Chile. For the case of Poland, the break in time series combined with a positive trend overall make it difficult to draw any conclusion. 
Figure 9: Total employment of multinational firms around the time of totalization agreements' effective dates

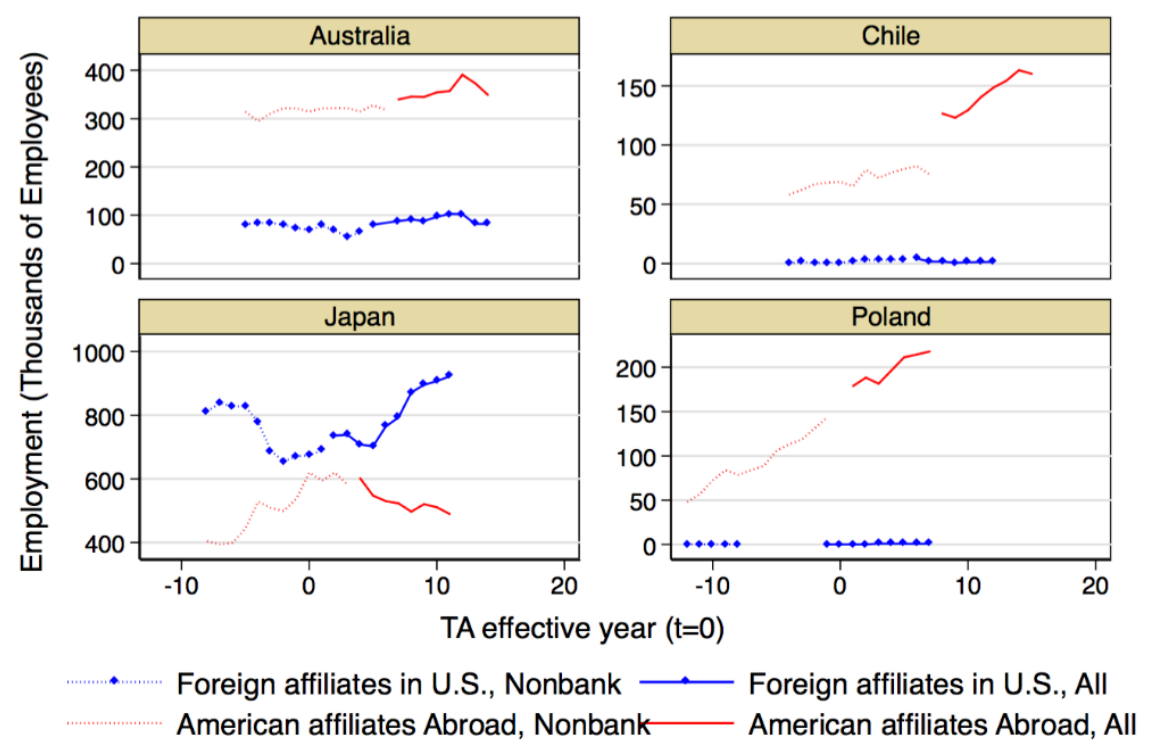

Source: $B E A$

Taxpayers who claim the foreign-earned income exclusion must submit tax Form 2555 to the IRS. Figure 10 shows the number of 2555 tax forms submitted to the IRS, for a few source-of-income countries that enacted totalization agreements during the data sample period. The totalization agreements with the Netherlands, Chile, and Australia became effective in, respectively, 1990, 2001, and 2002. The figure shows this variable's evolution over time as a proxy for the number of American workers earning income abroad in each of these countries. For the case of the Netherlands, the number of workers submitting 2555 forms is higher after 1991. Australia shows an increasing pattern up to the totalization agreement's implementation, then fluctuation in the following years. Chile shows no clear pattern around the time of enactment of the totalization agreements. 
Figure 10: Foreign-earned income credit exclusion forms 2555 submitted to IRS, by country of income source. (Left axis: The Netherlands and Australia; right axis: Chile)

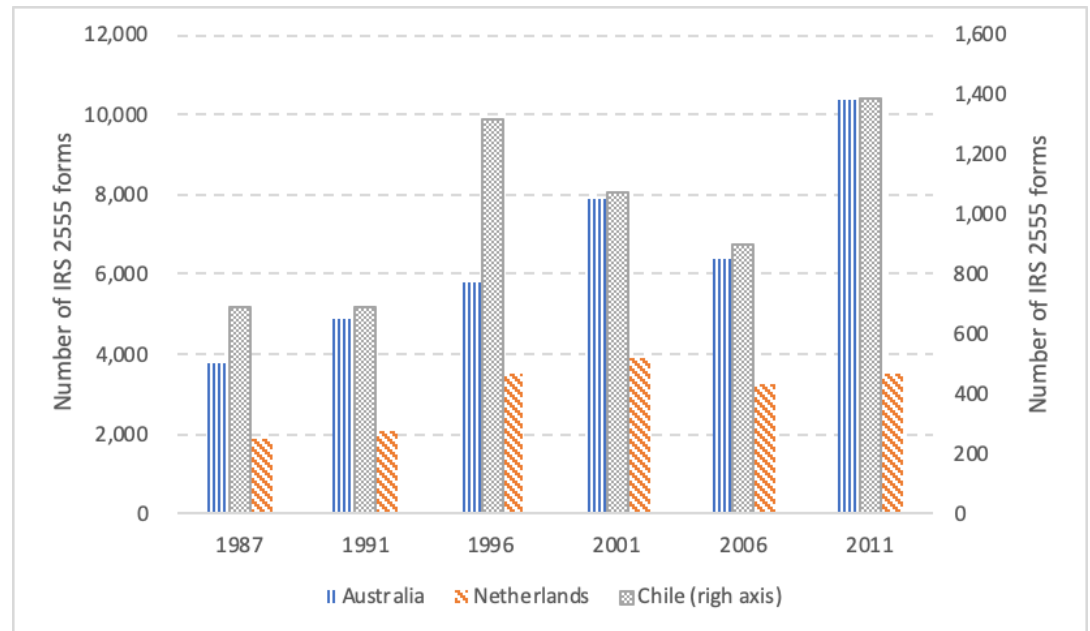

Source: IRS

To analyze the analog — the number of foreign workers who may come to the U.S. under a totalization agreement - we look at the evolution over time of certain nonimmigrant visa categories, which may serve as a proxy for this quantity. ${ }^{21}$ The data is available from the U.S. Department of State since 1997.

Figure 11 shows the number of these visa categories issued by the U.S. since 2000 until 2014 for nationals of three countries that signed totalization agreements during that period: Chile (2001), Japan (2005), and Poland (2009). There is no clear pattern across these countries around the agreement's effectiveness dates. Chile shows an increasing trend until 2010; Japan displays a continuously declining trend; finally, Poland shows a spike in 2006 , the year after the agreement came into effect.

\footnotetext{
${ }^{21}$ As mentioned previously, though not everyone coming to the U.S. with a certain type of visa necessarily is covered by a totalization agreement, changes in inflows from partner countries of individuals with the relevant visas are likely to be strongly correlated with changes in the number of individuals covered by an agreement.
} 
This later disappears and the annual number of visas after the agreement shows no clear trend. ${ }^{22}$

Figure 11: Number of nonimmigrant visas (E-1, E-2, H1-B, H1-B1, H2-B, L-1, and L2) issued by the U.S. by nationality of the worker

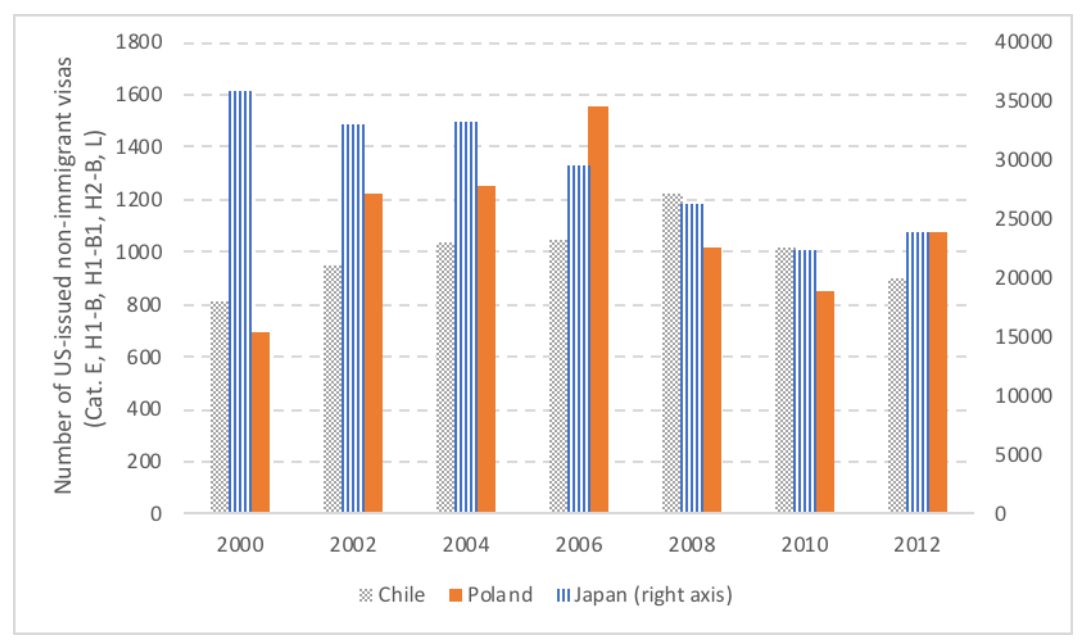

Source: U.S. Department of State

Using the available data for all 26 countries, we ran regressions of outward and inward FDI flows. The regressions correspond to the years 1966 to 2017, although data are not available for every country-year combination. Data are more often available for outgoing FDI than incoming FDI, so sample sizes for regressions for the former are larger $(1,194)$ than for the latter $(878)$.

The dependent variable is the inverse hyperbolic sine of outward FDI (in 2015 dollars), or the inverse hyperbolic sine of inward FDI (also in 2015 dollars). The inverse hyperbolic sine is very similar to a log transform for positive numbers that are not close

\footnotetext{
${ }^{22}$ Given the differential characteristics of each visa type, we analyzed these different visa categories separately to gain further insights. For example, the visa category $L-1$ for intracompany transferee for managerial and executive personnel is of particular interest to this question. However, this provided little information, as there is no pattern in the behavior over time for each individual visa category. The exception is Japan, where all visa categories considered show a declining trend over time.
} 
to zero, but is well-defined for zero and negative values as well and, therefore, is commonly used for variables that may have a nontrivial number of zeros or negative values. We used this because it happens occasionally that FDI is zero or negative, especially for incoming flows. The basic model includes country dummies, year dummies, and an "after" dummy for whether the treaty has taken effect. We also estimated specifications where we add dummies for the last three years before enactment and/or the first three years after, to capture anticipation or startup effects. We used two-way clustering of the standard errors by country and year (see, e.g., Cameron, Gelbach, and Miller 2011).

The results for the basic and most extensive models are reported in Table 7. The first two columns report FDI results of American firms abroad, while the third and fourth columns correspond to FDI by foreign firms in the U.S. For outgoing FDI, there is a large and statistically significant effect of the treaty taking effect. The coefficients translate roughly into a $15 \%$ to $25 \%$ jump in FDI after the treaty takes effect.

There is weak evidence for anticipation effects: The coefficients for the three years before the treaty takes effect are large and positive, but they are only significant at the $10 \%$ level. There is little evidence for gradual startup effects after the treaty takes effect: The coefficients are much smaller and not statistically significant (these coefficients are relative to more than three years after the treaty takes effect). The coefficients for incoming FDI also are large and positive, but these data are much more variable than the data for outgoing FDI (several countries have very low, even negative, net values of FDI to the U.S.), reflected in the large standard errors. Hence, we cannot draw firm conclusions about incoming FDI.

We have also estimated a specification where we add the (log) exchange rate versus the U.S. dollar and a dummy for whether the Euro had been adopted (= 1 in 
2002 or later for all Euro countries except Slovakia, where it is 2009 or later; $=0$ in all other cases). The coefficients of these two variables are far from statistically significant and they do not materially change the conclusions.

As seen in Figures 6 and 7, the countries are heterogeneous in terms of the size of their investments made in the U.S., and also in terms of the flows of investment they receive from America. Overall, the empirical evidence suggests that the totalization agreements affect multinational firms' decisions regarding location of foreign affiliates. However, the aggregate magnitude of these effects may be small. The effects' complexities require a look at the channels through which these treaties modify the firms' incentives. The effects for each pair of countries likely will depend on each country's relative advantages in terms of factor endowments, productivity, and tax rates. The next section highlights some of these considerations.

Table 7: Regression results for outward and inward FDI flows around the time of the totalization agreements effective dates

\begin{tabular}{lcccc}
\hline & $\begin{array}{c}(\mathbf{1}) \\
\text { Regressor }\end{array}$ & $\begin{array}{c}(\mathbf{2}) \\
\text { FDI of American }\end{array}$ & $\begin{array}{c}(\mathbf{3}) \\
\text { firms abroad }\end{array}$ & $\begin{array}{c}\mathbf{( 4 )} \\
\text { FDI of foreign }\end{array}$ \\
\hline After treaty & $0.329^{* *}$ & $0.492^{* *}$ & 0.478 & 1.065 \\
& $(0.125)$ & $(0.174)$ & $(0.703)$ & $(1.005)$ \\
Last year before & & $0.345^{*}$ & & 1.105 \\
& & $(0.139)$ & & $(0.660)$ \\
Second year before & & $0.334^{*}$ & & $1.256^{*}$ \\
& & $(0.132)$ & & $(0.615)$ \\
Third year before & & $0.280^{*}$ & & $1.422^{*}$ \\
& & $(0.113)$ & & $(0.596)$ \\
Year of treaty & & -0.087 & & -0.313 \\
& & $(0.122)$ & & $(0.715)$ \\
Second year & & -0.101 & & -0.124 \\
& & $(0.112)$ & & $0.447)$ \\
Third year & & -0.098 & & -0.053 \\
& & $(0.127)$ & & $0.440)$ \\
\hline $\mathbf{N}$ & & 1194 & 878 & 878 \\
$\mathbf{R}^{2}$ & 1194 & 0.829 & 0.755 & 0.759 \\
\hline
\end{tabular}

Note: Country dummies, year dummies, and constant included in the model but not shown. Standard errors in parentheses two-way clustered by country and year. ${ }^{*} p<0.10 ;{ }^{* *} p<0.05$; ${ }^{* * *} p<0.01$. 


\section{Quantitative framework}

\subsection{Theoretical model}

As a benchmark, we used a dynamic general equilibrium model of FDI, extending the quantitative framework of the world allocation of firm-embedded productivity developed by Burstein and Monge-Naranjo (2009). A long tradition in the literature links firm-embedded productivity to the management know-how and skills of individuals leading the firm. Management know-how is similar to codified technological knowledge, as it can be reallocated across sectors, regions, and, albeit imperfectly, countries. Burstein and Monge-Naranjo extended a standard neoclassical model to account for limited span of control by introducing management know-how as an additional factor of production. A model with a limited span of control is well suited for multinational production because it reflects managerial know-how, which shapes the firm's productivity, is difficult to reproduce at the affiliate level: A manager with certain abilities can control only a limited amount of production inputs at a given location.

In the model, firms are teams of managers, workers, and capital - as in Lucas (1978). Each country has domestic supplies of labor and of management skills, both of which can change over time. Managers can reallocate their skills and lead firms in foreign countries, where they face country-specific taxes. Capital can also be reallocated across countries. This reallocation of resources across borders gives rise to FDI in this model. ${ }^{23}$

${ }^{23}$ FDI measures include greenfield investments and mergers and acquisitions. In this model, greenfield FDI corresponds to a joint transfer of capital and firm-embedded productivity from the source to the host country. Mergers and acquisitions correspond to a transfer of firmembedded productivity with an ownership reassignment on existing capital. Other forms of capital inflows (such as portfolio equity flows or corporate debt) correspond in the model to capital investments by foreign agents, or capital transfers between domestic and foreign 
We adapted this model to incorporate U.S. and foreign social security and income taxes. These taxes may distort the compensation of managers and skilled workers who are relocated abroad and, thus, the firms' decisions about such relocations. The extent to which this happens depends on the existence of totalization agreements between countries. The model allows us to study the impact these treaties have on firms' foreign operations decisions. We did not explicitly model aspects relevant to workers' decisions, such as how moving abroad affects their Social Security eligibility. ${ }^{24}$ We focused on the effects of totalization agreements as analogous to payroll taxes in the firms' problem for the case of managers. This allowed us to account for the changes in the costs of sending employees abroad.

\subsubsection{Production at the firm level}

There is a single, freely-traded consumption good. Production of this good is carried out by firms, and requires capital services, labor services, and leadership. The firm has two types of employees: workers (who provide the labor services) and managers (who make decisions for the firm and provide know-how and management skills). The output of a firm that has $x$ units of management know-how, I units of labor, and $k$ units of physical capital, and is operating in country $i$ is given by a Cobb-Douglas type production function of the form $y=Z_{i} x_{i}^{\nu}\left(k^{\alpha} l^{1-\alpha}\right)^{1-v}$, where $v \in(0,1)$ is the share of

agents not complemented with inflows of foreign firm-embedded productivity. Finally, other management know-how transfers not associated with capital ownership (e.g., foreign managers working in a firm with domestically owned capital) correspond in the model to inflows of foreign embedded productivity with no changes in the quantity or ownership of capital, and are not included in any capital flow measure in the data.

${ }^{24}$ Under certain assumptions, such as risk neutrality and perfect foresight, the complex decision problem of a worker choosing between possible job offers affecting their future social security benefits is analogous to a simpler model where the compensation in each job offer is a sufficient statistic to capture the relevant differences in job benefits. 
management know-how in output and $\alpha(1-v) \in(0,1)$ is the share of physical capital in output. The term $Z_{i}$ reflects the country-specific productivity, as given by its infrastructure, laws and regulations, human capital levels, and other nontradeable aspects that affect production possibilities. Management skills $x$ determine firm-specific productivity and can be allocated across countries.

Managers decide in which country to establish the firm. They look to maximize their own pay and firm profits. When a firm from country $j$ sends firm-embedded productivity to country $i$, it produces output $y=Z_{i} x_{j}^{v}\left(k^{\alpha} l^{1-\alpha}\right)^{1-v}$. Managers compensation is $\pi_{i}$ if they work in country $i$ or $\pi_{j}$ if they work in country $j$. This type of cross-border allocation of management power (and firm-embedded productivity) is closely connected to the concept of FDI. ${ }^{25}$

\subsubsection{Taxation}

Governments in each country set taxes on income and payroll that apply to labor and managerial skills. Payroll tax rates may differ between domestic firm-embedded productivity $\left(\tau_{i}^{D}\right)$ and foreign firm-embedded productivity $\left(\tau_{i}^{F}\right)$. Managers from country $i$ receive a net salary of $\left(1-\tau_{i}^{D}\right) \pi_{i}$ if they work in country $i$ or $\left(1-\tau_{j}^{F}\right) \pi_{j}$ if they work in country $j$. As mentioned in Section 2, in most countries there is a cap to wages subject to social security, $g_{i}$, such that payroll taxes are only paid on earnings up to $g_{i}$. If $\pi_{i}>g_{i}$, the net-of-tax profits for managers are given by $\left(1-\tau_{i}^{D}\right) g_{i}+\left(\pi_{i}-g_{i}\right)$.

\footnotetext{
${ }^{25} \mathrm{FDI}$ is a category of cross-border investment made by a resident in one economy with the objective of establishing a lasting interest in an enterprise resident in an economy other than that of the direct investor. The motivation of the direct investor is a strategic, long-term relationship with the direct investment enterprise to ensure a significant degree of influence by the direct investor in the management of the direct investment enterprise. Direct investment may also allow the direct investor to gain access to the economy of the direct investment enterprise which it might otherwise be unable to do. (OECD 2008)
} 


\subsubsection{Equilibrium in a two-country case}

Country $i$ has an endowment of $L_{i}$ workers and an aggregate of $X_{i}$ units of firmspecific productivity or management skills. ${ }^{26}$ Workers are assumed to be immobile, remaining in their countries, but managers are internationally mobile and carry their know-how with them to whatever country they move to. Physical capital can be internationally traded, and the country's endowment is $K_{i}$. We assume that the country's endowments of workers, managers, and physical capital are fixed.

We assume factor prices are determined in competitive markets, and workers earn wages $w_{i}$ while managers are compensated at a rate $\pi_{i}$ per unit of managerial skill. All firms in country $i$ face the same factor prices. In equilibrium, factor prices equal the marginal product of each factor. Therefore, the firms' profits equal the managerial compensation, $\pi_{i}$. Appendix A.1 lists these equilibrium prices. Absent any differences among firms, all employ the same combination of workers and managers. Aggregate output in country $i$ is:

$$
Y_{i}=Z_{i} \bar{X}_{i}^{v}\left(\bar{K}_{i}^{\alpha} L_{i}^{1-\alpha}\right)^{1-v},
$$

where $\bar{X}_{i}$ represents the total net managerial power used in country $i$ and $\bar{K}_{i}$ is the total physical capital operating in country $i$. Due to international mobility of managers and capital, $\bar{X}_{i}$ and $\bar{K}_{i}$ may be smaller or larger than the country's endowments, $X_{i}$ and $K_{i}$. Analogous notation applies to country $j$. To obtain stylized results, we consider a

\footnotetext{
${ }^{26}$ We assume the labor force share of workers and managers to be fixed. Considering the low elasticity of labor to payroll contributions (Gruber 1997) and the relatively low share of multinational firms in the economy, it is unlikely that changes in double taxation derived from totalization agreements will have a first order impact on the individual decisions to become workers or managers, making this a safe simplifying assumption.
} 
simplified model in which the world consists of two countries. Hence, the world aggregate constraints for these factors are:

$$
\bar{X}_{i}+\bar{X}_{j}=X_{i}+X_{j} \text {, and } \bar{K}_{i}+\bar{K}_{j}=K_{i}+K_{j} .
$$

\section{Allocation of managerial effort}

The worldwide equilibrium allocates management know-how by equalizing its net-of-tax marginal product across countries. A country attracts more foreign management know-how the lower its domestic supply, the higher its country-specific productivity, and the lower its tax rate on the returns to foreign management know-how. These implications echo the results in Helpman (1984) that inflows of multinational firms are more prevalent in countries with a relative scarcity of factors intensively used by headquarter services (e.g., management, marketing, and R\&D), but with relative richness in factors used intensively in production activities (e.g., unskilled labor). Hence, we expect to find different effects of totalization agreements with developed countries than with developing economies.

The allocation of managerial effort across countries depends on their differences in terms of taxes on foreign managers, factor endowments, and the relative countryspecific productivity. In an interior equilibrium where country $i$ exports firm-embedded productivity to country $j$, net-of-tax profits for managers from country $i$ must be equal across both countries. In such an equilibrium, we define $X_{i j}$ implicitly and the share of firm-embedded productivity in country $j$ controlled by foreign firms is:

$$
s=\frac{X_{i j}}{\bar{X}_{j}}=\frac{\bar{X}_{j}-X_{j}}{\bar{X}_{j}}
$$

When the social security cap is binding in both countries, equalizing the net of tax

profits for managers leads to: $\left(1-\tau_{i}^{D}\right) g_{i}+\left(\pi_{i}-g_{i}\right)=\left(1-\tau_{j}^{F}\right) g_{j}+\left(\pi_{j}-g_{j}\right)$ if $\pi_{i}>g_{i}$ 
and $\pi_{j}>g_{i}$. But if $\pi_{i} \leq g_{i}$ and $\pi_{j} \leq g_{j}$, the equalization of net-of-tax profits for managers requires:

$$
\left(1-\tau_{i}^{D}\right) \pi_{i}=\left(1-\tau_{j}^{F}\right) \pi_{j}
$$

In this case, when taxes are such that $\frac{\left(1-\tau_{j}^{D}\right)}{\left(1-\tau_{i}^{F}\right)}>\frac{1-\tau_{j}^{F}}{1-\tau_{i}^{D}}$, this implies that $X_{i j}>0, X_{j i}=0$ (i.e., country $i$ is a source of FDI and country $j$ is the host.)

Appendix A.1 shows the derivation of the equilibrium level of foreign-controlled managerial power and the share of firm-embedded productivity controlled by foreign firms. These result in:

$$
\frac{\bar{X}_{j}}{\bar{X}_{i}}=\frac{\bar{K}_{j}^{\alpha} L_{j}^{1-\alpha}}{\bar{K}_{i}^{\alpha} L_{i}^{1-\alpha}}\left[\frac{\left(1-\tau_{i}^{D}\right) Z_{i}}{\left(1-\tau_{j}^{F}\right) Z_{j}}\right]^{1 / \nu-1}
$$

and

$$
s=\frac{1-\left[\frac{\left(1-\tau_{i}^{D}\right) Z_{i}}{\left(1-\tau_{j}^{F}\right) Z_{j}}\right]^{1 / 1-v}\left(\frac{\bar{K}_{i}^{\alpha} L_{i}^{1-\alpha}}{\bar{K}_{j}^{\alpha} L_{j}^{1-\alpha}}\right) \frac{X_{j}}{X_{i}}}{1+\frac{X_{j}}{X_{i}}} .
$$

The share of foreign firm-embedded production in country $j, s$, is higher when country $j$ is more productive, when it has more capital and labor and less managerial capacity relative to country $i$, when the taxes on foreign management are lower in country $j$, and when the taxes on own management are higher in country $i$.

The international movements of capital are determined by equalizing the return to physical capital across the countries, net of depreciation and taxes:

$$
\left(1-\tau_{i}^{K}\right)\left(r_{i}-\delta\right)=\bar{r}_{i}^{K}=r^{*}
$$

Substituting in the expressions for factor prices, we obtain the equilibrium level of physical capital operating in each country: 


$$
\bar{K}_{i}=\left\{\left[\frac{r^{*}}{\left(1-\tau_{i}^{K}\right)}+\delta_{i}\right] \frac{L_{i}^{-(1-\alpha)(1-v)}}{\alpha(1-v) Z_{i} \bar{X}_{i}^{v}}\right\}^{\frac{1}{\alpha(1-v)-1}}
$$

Consumption and investment

Assuming a stationary equilibrium with no growth implies the levels of consumption and the stock of capital are constant over time, in equilibrium: $C_{i, t}=$ $C_{i, t+1}=C_{i}$ and $K_{i, t}=K_{i, t+1}=K_{i}$. Therefore, investment is given by $I_{i}=K_{i, t+1}-$ $(1-\delta) K_{i, t}=\delta K_{i}$, where $\delta$ is the depreciation rate of physical capital. Government taxation is redistributed as lump sum transfers to consumers. In autarky, the economy resource constraint is given by: $C_{i}+\delta K_{i}=Y_{i}$. In an open economy, the economy's resource constraint takes into account the payment to and from foreign factors. If the country is a net source of managerial power, i.e. $X_{i j}>0$, the resource constraint in this economy is given by: $C_{j}+\delta \bar{K}_{j}=\left[1-\left(1-\tau_{j}^{F}\right) s v\right] Y_{j}+r^{*}\left(K_{j}-\bar{K}_{j}\right)$, which takes into account the revenues from factors producing abroad. Absorption (consumption plus investment) in each country equals aggregate output minus the net payments to foreign factors.

International trade balance

The trade balance of country $i$ is given by: $T B_{i}=Y_{i}-C_{i}-I_{i}$, which results in:

$$
T B_{i}=\left\{\begin{array}{l}
-\left(1-\tau_{j}^{F}\right) s v Y_{j}-r^{*} \underbrace{\left(K_{i}-\bar{K}_{i}\right)}_{>0}<0, \text { if } X_{i j}>0, \quad \text { and } \\
\left(1-\tau_{j}^{F}\right) s v Y_{j}-r^{*} \underbrace{\left(K_{i}-\bar{K}_{i}\right)}_{<0}>0, \text { if } X_{i j}<0 .
\end{array}\right.
$$

Thus, the model predicts that countries with net FDI outflows run a trade balance deficit as they have to make payments to foreign factors. Conversely, the country with the net 
FDI inflows runs a trade balance surplus with its partner country. ${ }^{27}$ Refer to Appendix A.1 for the proof.

\subsubsection{The effects of international social security totalization agreements}

Totalization agreements reduce the burden of payroll taxation for a firm's employees assigned abroad. This is reflected in a lower value of $\tau$ after the totalization agreement is put effectively in place. Appendix A.1 shows that, if country $i$ is a net sender of managers to country $j$, the model predicts that, by decreasing the foreign payroll tax rate for managers in country $j$, the totalization agreement increases the foreign share of production controlled by country $i$. This increase will be larger with higher ratios of capital, labor endowments, and country-specific productivity of country $i$ to country $j$.

The model predicts that the increase in the share of foreign-controlled capital in country $j$, given a tax decrease on foreign managers in that country, will be higher the more productive is the economy of country $j$, the less productive is country $i$, the higher is the ratio of the workforce size in country $j$ relative to country $i$, and the higher is the country i's tax on local managers. The derivation of this property is in Appendix A.1. Based on the information presented in Sections 2 and 3, this indicates that a totalization agreement's effect with the U.S. would be different for Chile, Germany, or Japan. The next section explores whether the effect of a totalization agreement with Germany or Japan may be stronger for inward FDI to the U.S. than for outward FDI.

${ }^{27}$ This is a well-known characteristic of international firm production models with horizontal integration. The way to overcome this (mostly counterfactual) correlation between FDI flows and trade flows is to allow for vertical integration of multinational production (see Irarrazabal et al. 2013). 


\subsection{Numerical exercises}

We used the calibrated model to simulate the steady-state levels of economic output, capital investment, and factor prices under scenarios where the totalization agreements are or are not in effect. The difference between these two cases (with or without totalization agreements) provides an estimate of the totalization agreements' impact on the outcomes of interest. It is worth noting that these effects are isolated from everything else that affects firms' decisions regarding the location of their activities. We do not speak to any of the channels not included in the model.

Totalization agreements' effect on macroeconomic outcomes is likely to vary by partner country for two main reasons. First, the differences in the provisions of totalization agreements mentioned in Section 2 can imply different effects by reducing or strengthening the propagation channel in the model. For example, the totalization agreement with Italy does not include a "detached-worker rule," in which a person who is temporarily transferred to work for the same employer in another country remains covered only by the country from which he or she has been sent, whereas other totalization agreements do include such a rule. Second, the characteristics of the countries (such as their labor force composition, productivity, etc.) affect the extent to which a totalization agreement has an impact on the outcomes of interest.

Though it was not within this project's scope to analyze the impacts of each of the individual totalization agreements, this model provides insights into how totalization agreements' impacts likely vary depending on the type of agreement and country characteristics. Given data availability and variation in country characteristics, we selected three cases of totalization agreements and used our model to show how their impacts may vary. In particular, the effects of totalization agreements signed with developed industrialized countries are expected to be different than those of 
agreements signed with developing countries: Larger economies are more complementary to the U.S. in terms of investment opportunities for American investors and workforce composition, while less developed economies provide more opportunities to profit from relative advantages.

Because of this, we performed simulations for Germany, which signed a totalization agreement with the U.S. in 1979, Japan (2005), and Chile (2001). For Japan and Chile, we used the model to simulate the equilibrium effect of these treaties and compare it with the state of the economy at the time of implementation. The necessary data for Germany do not go back to 1979 . To overcome this difficulty, we used the most recent data available to perform a counterfactual exercise evaluating the effects if the agreement were to be cancelled. The model parameterization and quantification are described in Appendix A.2.

On average, workers under totalization agreements have salaries above the contribution caps for social security. To account for this, we approximate the social security tax rates with the effective tax rates after taking into account the salary cap for social security contributions. ${ }^{28}$ Details are in Appendix A.2. We use these rates (Tables A.3 and A.4 in Appendix A.2) to compute the differentials in effective payroll tax rates on foreign managers implied by the implementation of the totalization agreements, shown in Table 8. These differentials indicate that the totalization agreements made FDI flows between the U.S. and the partner countries less expensive, indicating that both inward and outward FDI flows should increase in the U.S. as a result.

\footnotetext{
${ }^{28}$ Totalization agreements cover the U.S. Medicare portion of social security taxes. Therefore, in the calculations for the U.S. Social Security payroll taxes, we include the $12.4 \%$ OASDI tax (subject to an earnings cap) and the $2.9 \%$ Medicare tax on earnings.
} 
Table 8: Changes in implied effective tax rate (in percentage points) as consequence of totalization agreements implementation

\begin{tabular}{lcll}
\hline & Origin country: U.S. & \multicolumn{2}{c}{$\begin{array}{l}\text { Destination country: } \\
\text { U.S. }\end{array}$} \\
$\begin{array}{l}\text { Destination } \\
\text { country: }\end{array}$ & & $\begin{array}{l}\text { Origin } \\
\text { country: }\end{array}$ & \\
\hline Japan & -17.8 & Japan & -15.3 p.p. \\
Chile & p.p. & Chile & -15.3 p.p. \\
Germany & -2.1 p.p. & Germany & -15.3 p.p \\
\hline
\end{tabular}

\subsubsection{Simulation and counterfactual exercises}

We used data to quantify the model equilibrium at the time of the agreements' implementations, as explained in Appendix A.2. We then evaluated the impact of the agreements on FDI flows and other macroeconomic variables. Table 10 shows the results from these exercises, indicating how different outcomes change relative to the baseline. These simulations are for illustration of the potential magnitude of these effects, assuming all other factors driving FDI decisions besides taxes remain constant.

Japan: The model predicts that on net, the implementation of this totalization agreement increased the incentives of Japanese firms to reallocate their operations to the U.S., resulting in net FDI inward flows from Japan to the U.S. The empirical evidence in Section 2 showed that Japan had large FDI in the U.S., resulting in the U.S. having net liabilities with Japan, even before 2005. This indicates that the implementation of the totalization agreement with Japan incremented Japanese investments in the U.S., both in the form of capital as well as managerial power. This would have acted on top of any other influences driving up Japan's inward FDI before the treaty.

Chile: The totalization agreement decreased the average foreign effective tax rate on managers from U.S. firms affiliates in Chile by 15.3 percent points. According to 
the model, the manager allocations between Chile and the U.S. were almost balanced before the totalization agreement; there was no incentive for further affiliates. But the totalization agreement's implementation increased the incentives of American firms to send managers and investments to their Chilean affiliates. The totalization agreement with Chile increased American firms' incentives to engage in FDI in that country. This is not at odds with the evidence in Section 3.5, where assets and employment levels of American affiliates in Chile showed positive growth around the time of the implementation of the treaty.

Germany: The counterfactual exercise about Germany consists in simulating the effects of removing the totalization agreement in 2015 , which is as recently as allowed by the available data. This simulation predicts that the current totalization agreement makes the net flow of investments between the U.S. and Germany almost even, with a slight balance in favor of the U.S. If the agreement were to be removed, U.S. firms would decrease their outward FDI flows to German affiliates and German firms would increase their FDI flows to the U.S. in such a magnitude that the German FDI inflows to the U.S. would be larger than the U.S. FDI outflows to Germany. This implies that this agreement is facilitating American investments in Germany beyond other forces. The U.S. has become a net investor in German capital as a consequence. 
Table 10: Summary of simulations for totalization agreement effects on Japan, Chile, and Germany

\begin{tabular}{|c|c|c|c|}
\hline & \multicolumn{3}{|c|}{ Totalization agreement } \\
\hline & \multicolumn{2}{|c|}{ Effect of implementation } & \multirow{2}{*}{$\begin{array}{c}\begin{array}{c}\text { Counterfactual } \\
\text { elimination }\end{array} \\
\text { Germany (2015) }\end{array}$} \\
\hline & Japan (2005) & Chile (2001) & \\
\hline Host country & U.S. & Chile & Germany \\
\hline \multicolumn{4}{|l|}{$\begin{array}{l}\text { Relative changes in } \\
\text { outcomes: }\end{array}$} \\
\hline$\Delta \tau_{\mathrm{F}}$ (in percentage points) & -15.3p.p. & -2.1p.p. & -7.8p.p. \\
\hline $\begin{array}{l}\Delta \text { foreign-controlled share } \\
\text { of production of host } \\
\text { country (percentage } \\
\text { change) }\end{array}$ & $+6.2 \%$ & $+2.8 \%$ & $-6.4 \%$ \\
\hline$\Delta$ capital flows & From host & To host & To host \\
\hline $\begin{array}{l}\Delta \text { trade balance of the U.S. } \\
\text { with partner country }\end{array}$ & Increase (surplus) & Decrease (deficit) & Increase (surplus) \\
\hline
\end{tabular}

By construction, the model assumes the forces that explain FDI flows are differences between countries in endowments (labor, physical capital, and firmembedded productivity), country-specific productivity, and payroll taxes. Under these assumptions, totalization agreements have significant impacts on the countries' allocation of management talent (and FDI decisions).

\section{Conclusions}

Social security international totalization agreements reduce double taxation on social security burdens and reduce the risk of not qualifying for social security benefits for persons working in a foreign country during part of their careers. Hence, these agreements make it more attractive for individuals to temporarily work abroad and increase employers' incentives to invest in the foreign country and send their workers to oversee operations in partner countries. 
As the number of totalization agreements with partner countries has increased, the number of workers covered by the agreements has correspondingly increased exponentially. However, the magnitude of these flows is small relative to the overall workforce. From the data, we infer there are no large effects on labor mobility induced by totalization agreements.

We find evidence that these agreements are associated with higher flows of FDI in and out of the U.S. The evidence suggests an impact of totalization agreements on the outward flows of FDI from the U.S. to foreign countries, but it is not as clear with respect to inward flows. Measuring the effects of these agreements in reduced form is challenging because the characteristics of the partner economies and their social security systems affect not only the size but also the direction of the effects on net flows of investment.

To overcome this limitation, we use a stylized macroeconomic model to generate predictions of the expected effects from these agreements. The model suggests that firms in the U.S. are more likely to benefit from the economic opportunity provided by a totalization agreement than firms in foreign countries.

The agreements affect the fraction of income that has to be paid in payroll taxes and which country's social security system receives these taxes. The model shows that such an agreement, by decreasing the cost of relocating productive inputs across borders, increases the flows of foreign capital and investments a country receives. The FDI flows of U.S. firms increase with the enactment of totalization agreements. The increase in the share of foreign-controlled capital in a (host) country, given a decrease in the tax on foreign managers in that country, will be higher the more productive is the economy of country $j$, the less productive is country $i$, the higher is the ratio of the 
workforce size in country $j$ relative to country $i$, and the higher is the country $i$ 's tax on local managers.

The quantitative exercises predict that the totalization agreement increased the incentives of Japanese firms to reallocate their operations to the U.S., resulting in net inward investment flows from Japan to the U.S. For Chile, however, the quantitative exercise indicates that the agreement made it more profitable for American firms to send managers and investments to their Chilean affiliate, indicating that the direction of the net effect depends on the relative characteristics of the partner country. The counterfactual exercise about Germany simulated the effects of removing the existing totalization agreement. This simulation predicts that if the agreement were removed, U.S. firms would decrease their investments in their German affiliates and German firms would increase flows of capital and investment to the U.S. The results suggest that this agreement almost evens out German investments in the U.S. and U.S. investments in Germany (due to the channels considered within the model), preventing the U.S. from being a net receptor of German investments.

Taken together, the empirical evidence and quantitative model indicate that totalization agreements facilitate the reallocation of productive factors and investments across borders by making it cheaper for multinational firms to expand their operations abroad. Increased economic production affects factor payments, workers incomes, and government revenues. The magnitudes and direction of those impacts depend on the combination of characteristics of the U.S. and the partner country. 


\section{References}

Beck, S., \& Chaves, A. (2012). The impacts of various taxes on foreign direct investment. US Bureau of Economic Analysis or the US Department of Commerce.

Börsch-Supan, A. (2018). Survey of Health, Ageing and Retirement in Europe (SHARE) Wave 1. Release version: 6.1.0. SHARE-ERIC. Data set. DOI: 10.6103/SHARE.w1.610

Börsch-Supan, A., M. Brandt, C. Hunkler, T. Kneip, J. Korbmacher, F. Malter, B. Schaan, S. Stuck, S. Zuber (2013). Data Resource Profile: The Survey of Health, Ageing and Retirement in Europe (SHARE). International Journal of Epidemiology. DOI: 10.1093/ije/dyt088

Börsch-Supan, A. and H. Jürges (Eds.) (2005). The Survey of Health, Ageing and Retirement in Europe - Methodology. Mannheim: Mannheim Research Institute for the Economics of Aging (MEA).

Burstein, A. T., \& Monge-Naranjo, A. (2009). Foreign know-how, firm control, and the income of developing countries. The Quarterly Journal of Economics, 124, 149-195.

Cameron, A. C., Gelbach, J. B., \& Miller, D. L. (2011). Robust inference with multiway clustering. Journal of Business \& Economic Statistics, 29, 238-249.

De Mooij, R. A., \& Ederveen, S. (2003). Taxation and foreign direct investment: a synthesis of empirical research. International Tax and Public Finance, 10, 673-693.

Egger, P., \& Maria Radulescu, D. (2011). Labor taxation and foreign direct investment. The Scandinavian Journal of Economics, 113(3), 603-636. 
Egger, P., Radulescu, D., \& Strecker, N. (2013). Effective labor taxation and the international location of headquarters. International Tax and Public Finance, 20(4), 631-652.

Encuesta Nacional de Empleo (2010). Instituto Nacional de Estadísticas de Chile. https://www.ine.cl/estadisticas/laborales/ene

Feenstra, R. C., Inklaar, R., \& Timmer, M. P. (2015). The next generation of the Penn World Table. American Economic Review, 105(10), 3150-82, available for download at www.ggdc.net/pwt (DOI: 10.15141/S50TOR)

Flood, S., King, M., Rodgers, R., Ruggles, S., and Warren, J.R.. Integrated Public Use Microdata Series, Current Population Survey: Version 6.0 [dataset]. Minneapolis, MN: IPUMS, 2018. https://doi.org/10.18128/D030.V6.0

Gruber, J. (1997). The incidence of payroll taxation: evidence from Chile. Journal of Labor Economics, 15(S3), S72-S101.

Hansson, A., \& Olofsdotter, K. (2014). Labor Taxation and FDI decisions in the European Union. Open Economies Review, 25(2), 263-287.

Helpman, E. (1984). A Simple Theory of International Trade with Multinational Corporations. Journal of Political Economy, 92, 451-471.

International Labour Organization [ILO] (2017). World Social Protection Report 2017-19: Universal social protection to achieve the Sustainable Development Goals. Geneva: International Labour Office. http://ilo.org/global/publications/books/WCMS 604882/lang--en/index.htm

Irarrazabal, A., Moxnes, A., \& Opromolla, L. D. (2013). The margins of multinational production and the role of intrafirm trade. Journal of Political Economy, 121(1), 74-126.

Jackson, B. W., \& Cash, S. (2018). Social Security Totalization Agreements. Social Security Bulletin, 78(4), 1-11. 
Japan 2005 Population Census (2007). Ministry of Internal Affairs and Communications, Statistical Tables.

\section{https://www.stat.go.jp/english/data/kokusei/2005/kihon3/00/index.html}

Lane, P. R., \& Milesi-Ferretti, G. M. (2007). The external wealth of nations mark II: Revised and extended estimates of foreign assets and liabilities, 1970-2004. Journal of international Economics, 73(2), 223-250.

Lucas, R. E. Jr. (1978). On the Size Distribution of Business Firms. Bell Journal of Economics, 9, 508-523.

OECD (2009). OECD Benchmark Definition of Foreign Direct Investment (4th ed.). OECD Publishing, Paris, https://doi.org/10.1787/9789264045743-en.

—; - (2019). FDI stocks (indicator). https://doi.org/10.1787/80eca1f9-en

Ramondo, N. (2014). A quantitative approach to multinational production. Journal of International Economics, 93, 108-122.

Social Security Administration (2018a). Annual Statistical Supplement to the Social Security Bulletin. Available on the web at https://www.ssa.gov/policy/docs/ statcomps/supplement/.

-; - (2018b). Social security programs throughout the world: Europe, 2018. SSA Publication No. 13-11801. Washington, DC.

-; - (2018c). Social security programs throughout the world: The Americas, 2017. SSA Publication No. 13-11804. Washington, DC.

-; - (2019). Social security programs throughout the world: Asia and the Pacific, 2018. SSA Publication No. 13-11802. Washington, DC.

U.S. Bureau of Economic Analysis or the US Department of Commerce. (2018a) Activities of U.S. Multinational Enterprises, 2017.

(2018b) Activities of U.S. Affiliates of Foreign Multinational Enterprises, 2016. 


\section{Appendices}

\section{A.1 Equilibrium of the theoretical model}

In a competitive equilibrium, the price of each factor equals its marginal productivity, thus the wage for workers is

$$
w_{i}=(1-\alpha)(1-v) Y_{i} / L_{i},
$$

the price of managerial know-how is

$$
\pi_{i}=v Y_{i} / X_{i}
$$

and the rental rate for capital is

$$
r_{i}=\alpha(1-v) Y_{i} / K_{i}
$$

Share of firm-embedded productivity in country $j$ controlled by foreign firms

If, in equilibrium, country $i$ is the source of managerial power, and country $j$ is the host, then $X_{i j}>0$ and $X_{j i}=0$, thus: $\bar{X}_{i}=X_{i}-X_{i j}$. We solve the case when the social security wage caps are not binding. The qualitative properties follow to the case with binding caps, but this approximation allows us to obtain closed-form solutions for most outcomes. The allocation of firm-specific know-how is done through the equalization of the firms returns, net of tax, shown in equation (4). If taxes are such that

$$
\frac{1-\tau_{j}^{F}}{1-\tau_{i}^{D}}<\frac{1-\tau_{j}^{D}}{1-\tau_{i}^{F}}
$$

then $\left(1-\tau_{i}^{F}\right) \pi_{i}<\left(1-\tau_{j}^{D}\right) \pi_{j}$, which is a condition for country $i$ to be the source and country $j$ the host. To find the equilibrium level of $\bar{X}_{i}$, we use equations (a.2) and (3) in (a.4): 


$$
\begin{aligned}
\frac{\left(1-\tau_{i}^{D}\right) Y_{i}}{\bar{X}_{i}} & =\frac{\left(1-\tau_{j}^{F}\right) Y_{j}}{\bar{X}_{j}} \\
\left(1-\tau_{i}^{D}\right) v Z_{i}\left(X_{i}-X_{i j}\right)^{v-1}\left(\bar{K}_{i}^{\alpha} L_{i}^{1-\alpha}\right)^{1-v} & =\left(1-\tau_{j}^{F}\right) v Z_{j}\left(X_{j}+X_{i j}\right)^{v-1}\left(\bar{K}_{j}^{\alpha} L_{j}^{1-\alpha}\right)^{1-v}
\end{aligned}
$$

Using the definition of $X_{i j}$ in (a.6):

$$
\left[\frac{\left(1-\tau_{i}^{D}\right) Z_{i}}{\left(1-\tau_{j}^{F}\right) Z_{j}}\right]^{1 / v-1}\left(\frac{\bar{K}_{i}^{\alpha} L_{i}^{1-\alpha}}{\bar{K}_{j}^{\alpha} L_{j}^{1-\alpha}}\right)^{-1} \bar{X}_{i}=\bar{X}_{j}
$$

Using the world aggregate constraint:

$$
\bar{X}_{j}=\frac{1}{\left[\frac{\left(1-\tau_{i}^{D}\right) Z_{i}}{\left(1-\tau_{j}^{F}\right) Z_{j}}\right]^{1 / 1-v}\left(\frac{\bar{K}_{i}^{\alpha} L_{i}^{1-\alpha}}{\bar{K}_{j}^{\alpha} L_{j}^{1-\alpha}}\right)+1}\left(X_{i}+X_{j}\right)
$$

Therefore:

$$
s=\frac{1-\left[\frac{\left(1-\tau_{i}^{D}\right) Z_{i}}{\left(1-\tau_{j}^{F}\right) Z_{j}}\right]^{1 / 1-v}\left(\frac{\bar{K}_{i}^{\alpha} L_{i}^{1-\alpha}}{\bar{K}_{j}^{\alpha} L_{j}^{1-\alpha}}\right) \frac{X_{j}}{X_{i}}}{1+\frac{X_{j}}{X_{i}}}
$$

The share of foreign firm-embedded production in country $j$ is higher when country $j$ is more productive, when it has more capital, more labor, less own managerial power relative to country $i$, when the taxes on foreign management are lower in country $j$ and when the taxes on own management are higher in country $i$.

Consumption and investment

Aggregate consumption in each country equals aggregate output minus the net payments to foreign management know-how. Government taxation is redistributed as lump sum transfers to consumers.

Assuming a stationary equilibrium with no growth implies the levels of consumption and the stock of capital are constant over time, in equilibrium: $C_{i, t}=C_{i, t+1}$ 
and $K_{i, t}=K_{i, t+1}=K_{i}$. Therefore, $I_{i}=K_{i, t+1}-(1-\delta) K_{i, t}=\delta K_{i}$. In autarky, the economy resource constraint is then given by: $C_{i}+\delta K_{i}=Y_{i}$.

In the open economy, if $X_{i j}>0$, the economy's resource constraint takes into account the revenues from factors producing abroad and is given by: $C_{i}+\delta \bar{K}_{i}=Y_{i}+$ $\left(1-\tau_{j}^{F}\right) \pi_{j} X_{i j}+r^{*}\left(K_{i}-\bar{K}_{i}\right)=Y_{i}$. This implies that

$$
C_{j}+\delta \bar{K}_{j}=\left[1-\left(1-\tau_{j}^{F}\right) s v\right] Y_{j}+r^{*}\left(K_{j}-\bar{K}_{j}\right)
$$

consumption in the host country $j$ increases when it receives more FDI. However, whether the agreement makes the level of consumption in source country $i$ increase or decrease depends on whether the extra revenues from FDI are enough to compensate for the resulting decrease in output in country $i$.

To compute the ratio of physical capital operating in each country, $\bar{K}_{i} / \bar{K}_{j}$, and the ratio of managerial power in use in each country, $\bar{X}_{j} / \bar{X}_{i}$, we use the no-arbitrage condition on physical capital allocation, (6), and the equalization of firm profits used to solve the allocation of managerial power across countries, (a.7). We obtain a system of two equations in two unknowns which results in

$$
\frac{\bar{K}_{i}}{\bar{K}_{j}}=\frac{L_{j}}{L_{i}}\left(\frac{Z_{j}}{Z_{i}}\right)^{\frac{1}{(1-v)(1-\alpha)}}\left\{\frac{\frac{r^{*}}{\left(1-\tau_{i}^{K}\right)}+\delta_{i}}{\frac{r^{*}}{\left(1-\tau_{j}^{K}\right)}+\delta_{j}}\left[\frac{\left(1-\tau_{i}^{D}\right)}{\left(1-\tau_{j}^{F}\right)}\right]^{v / v-1}\right\}^{\frac{1}{1-\alpha}} .
$$

The effect of international social security totalization agreements

Totalization agreements reduce the burden of payroll taxation for the firm employees who are allocated abroad. This is reflected on a lower value of $\tau^{F}$ after the totalization agreement is effective. To analyze the qualitative impact of totalization agreements, we consider what happens to the share of inputs of country $j$ controlled by a foreign country $i$ in an equilibrium with such an agreement in place. We take 
derivatives of the equilibrium ratio of physical capital operating in each country with respect to the tax rate using equation (a.9):

$$
\frac{\delta\left(\frac{\bar{K}_{j}}{\bar{K}_{i}}\right)}{\delta \tau_{j}^{F}}=-\frac{v}{(1-v)(1-\alpha)} \frac{\bar{K}_{j}}{\bar{K}_{i}}\left(1-\tau_{j}^{F}\right)^{-1}<0
$$

A totalization agreement, by decreasing the effective value of $\tau_{j}^{F}$, increases the ratio of physical capital operating in the host country with respect to the source country. Taking derivatives of (a.7) indicates the impact on the flow of foreign managerial power:

$$
\frac{\delta\left(\frac{\bar{X}_{j}}{\bar{X}_{i}}\right)}{\delta \tau_{j}^{F}}=-\frac{1}{1-v} \frac{1}{1-\tau_{j}^{F}}\left(1-\frac{\alpha v}{1-\alpha}\right) \frac{\bar{X}_{j}}{\bar{X}_{i}} .
$$

For a wide range of plausible parameterizations of the model, including the one we use (see Table A.1), $\frac{\alpha v}{1-\alpha}<1$, therefore $\frac{\delta}{\delta \tau_{j}^{F}}\left(\frac{\bar{x}_{j}}{\bar{X}_{i}}\right)<0$. We use this result to evaluate changes in the share of foreign-controlled inputs:

$$
\frac{\delta s}{\delta \tau_{j}^{F}}=\frac{\delta}{\delta \tau_{f}^{F}}\left(\frac{\bar{X}_{j}-X_{j}}{\bar{X}_{j}}\right)_{X_{j} \text { is fixed }}^{=} \frac{X_{j}}{\bar{X}_{j}^{2}} \frac{\delta \bar{X}_{j}}{\delta \tau_{f}^{F}}<0
$$

Thus, the model predicts that, by decreasing the host country's effective payroll tax rate for foreign managers, a totalization agreement causes the foreign share of production controlled by the source to increase. This increase will be larger the lower is the share of foreign-controlled production in the host country. 


\section{A.2 Quantitative exercises}

Data

We quantified the model using data on output $Y($ GDP), aggregate employment $N$, physical capital operating in each country $(\bar{K})$, and the average depreciation rate of physical capital $\left(\delta_{K}\right)$ from the Penn World Table (version 9.0, Feenstra et al. 2015).

There are two ways to measure of the share of inputs controlled by foreign firms, s. One is the share of labor employed by foreign firms and the other is the net share of capital controlled by foreign firms. We follow Burstein and Monge-Naranjo and proxy for the latter using data on FDI stocks. Because our simulations are partial equilibrium between only two countries, abstracting from the rest of the countries, we need to compute the share of the FDI stock corresponding to the partner country (as opposed to all the countries).

$$
s_{j i}=\frac{\text { inward FDI stock in } j \text { from } i-\text { outward FDI stock from } j \text { to } i}{\text { total capital stock in country } i}
$$

We used data on FDI stocks from the updated and extended version of the the dataset constructed by Lane and Milesi-Ferretti (2007) for the earlier years. We complement this with data from the OECD (2019) for the later years. For the earlier years, the FDI stocks are not available by partner country. Therefore, we use data from the BEA on FDI flows to approximate the share of the stocks corresponding to one source/host country by accounting for the average share of FDI flows from/to this country.

For the relative size of workers with respect to managers in the labor force, we use data from the Current Population Survey (CPS), the Japan 2005 Population Census, the Chilean National Employment Survey (Encuesta Nacional de Empleo, ENE) and the Survey for Health, Ageing and Retirement in Europe (SHARE) for Germany. We compute the share of the employed population who are not managers or 
chief executives in the private sector, and that is our measure of workers in the economy, L/N. Table A.1 presents all these data.

Table A.1: Variable values for simulations

\begin{tabular}{|c|c|c|c|c|c|c|c|}
\hline & \multicolumn{2}{|c|}{2005} & \multicolumn{2}{|c|}{2001} & \multicolumn{2}{|c|}{2015} \\
\hline & & Japan & USA & Chile & USA & Germany & USA \\
\hline$Y$ & GDP & $4,846,675$ & $15,578,813$ & 223,073 & $13,430,655$ & $3,790,519$ & $18,181,462.4$ \\
\hline$N$ & $\begin{array}{l}\text { Workforce } \\
\text { (millions) }\end{array}$ & 65.78 & 142.56 & 5.37 & 138.77 & 42.44 & 150.28 \\
\hline $\bar{K}$ & $\begin{array}{l}\text { Capital in } \\
\text { use }\end{array}$ & $22,756,220$ & $49,681,637$ & 602,675 & $44,942,704$ & $16,146,003$ & $57,602,328$ \\
\hline $\begin{array}{l}1- \\
\text { L/N }\end{array}$ & $\begin{array}{l}\text { Share of } \\
\text { managers }\end{array}$ & $2.20 \%$ & $2.32 \%$ & $2.10 \%$ & $3.30 \%$ & $2.68 \%$ & $2.15 \%$ \\
\hline \multicolumn{2}{|c|}{ Outward FDI stock } & 469,181 & $3,714,875$ & 15,688 & $2,266,383$ & $1,362,452$ & $6,059,271$ \\
\hline \multicolumn{2}{|c|}{ Inward FDI stock } & 122,459 & $2,809,802$ & 58,203 & $2,032,590$ & 795,496 & $5,731,383$ \\
\hline$\delta$ & $\begin{array}{l}\text { Depreciation } \\
\text { rate of } \\
\text { capital }\end{array}$ & $4.3 \%$ & $4.2 \%$ & $3.3 \%$ & $4.2 \%$ & $3.8 \%$ & $4.9 \%$ \\
\hline
\end{tabular}

Note: Monetary values are in millions of 2015 USD.

\section{Parameter values}

The parameters of the model are mostly standard parameters in macroeconomic models - such as the depreciation rate of capital $(\delta)$ and the share of physical capital in the production function $(\alpha v)$ - and one model-specific parameter, which is the share of management in the production function $(v)$. We use data on the average depreciation rate of capital for each country from the Penn World Table. We follow Burstein and Monge-Naranjo's parameterization for $\alpha$ and $v$, shown in Table A.2.

Table A.2 Parameter values

Parameter

Depreciation rate of capital

Share of physical capital

Share of management

Relative share of physical

capital
Value by country

$\delta$

$\begin{array}{cc}\alpha(1-v) & 0.25 \\ v & 0.15 \\ \alpha & 0.29\end{array}$


Burstein and Monge-Naranjo choose the output share of capital so that the annual return to capital before taxes is equal to $5.5 \%$. They set $v$ so that the share of nonmanagement labor in output, $(1-\alpha)(1-v)$, is equal to $60 \%$. This is the product of $67 \%$, the average labor share in U.S. GDP over the period 1996 to 2000 (calculated, using data from the BEA, as the ratio of employee compensation to GDP, net of indirect taxes, subsidies, and proprietor's income), and $90 \%$, the share of wage compensation in nonmanagement occupations relative to total wage compensation in 2006 (wage compensation by occupation is calculated as the product of employment and average wage, using data from the Bureau of Labor Statistics).

$\underline{\text { Inferring model variables using aggregate data }}$

We can infer the endowment ratios of firm-embedded productivity by replacing equilibrium prices (a.2) in the arbitrage condition for international allocation of management know-how (4), and combining that with the world aggregate constraint on management know how and the definition of $s$, to obtain:

$$
s=\frac{1-\frac{\left(1-\tau_{i}^{D}\right) Y_{i} X_{j}}{\left(1-\tau_{j}^{F}\right) Y_{j} X_{i}}}{1+\frac{X_{j}}{X_{i}}} \text {, and thus: } \frac{X_{j}}{X_{i}}=\frac{1-s}{s+\frac{\left(1-\tau_{i}^{D}\right) Y_{i}}{\left(1-\tau_{j}^{F}\right) Y_{j}}}
$$

We use the information about the share of foreign-controlled inputs, $s$, and the aggregate product of each country on the benchmark year to compute the ratio of firmembedded productivity endowments. Note that the units of managerial skills might well be different than the actual number of managers in the workforce, hence this ratio is a better approximation.

Using the definition of aggregate product (1), equilibrium prices (a.1 to 3 ) and the arbitrage condition for international allocation of management know-how (4), we obtain: 


$$
\frac{Z_{i}}{Z_{j}}=\frac{\left(1-\tau_{j}^{F}\right)^{v} Y_{i}^{1-v}\left(\bar{K}_{j}^{\alpha} L_{j}^{1-\alpha}\right)^{1-v}}{\left(1-\tau_{i}^{D}\right)^{v} Y_{j}^{1-v}\left(\bar{K}_{i}^{\alpha} L_{i}^{1-\alpha}\right)^{1-v}}
$$

We use data for factors, output, and taxes during the benchmark year to obtain the policy-invariable ratio of country-specific productivities. Knowing the optimal capital ratio after a change in taxes from Equation (a.9), we use it in Equation (a.10) to compute the new ratio of output in equilibrium:

$$
\frac{Y_{j}}{Y_{i}}=\left(\frac{1-\tau_{j}^{F}}{1-\tau_{i}^{D}}\right)^{\frac{v}{1-v}}\left(\frac{Z_{j}}{Z_{i}}\right)^{\frac{1}{1-v}} \frac{\left(\bar{K}_{j}^{\alpha} L_{j}^{1-\alpha}\right)}{\left(\bar{K}_{i}^{\alpha} L_{i}^{1-\alpha}\right)}
$$

$\underline{\text { Capital taxes }}$

We back up the capital tax rates from the no-arbitrage condition, Equation (6):

$$
\begin{gathered}
r^{*}=\left(1-\tau_{i}^{K}\right)\left(\frac{\alpha(1-v) Y_{i}}{\bar{K}_{i}}-\delta_{i}\right) \\
\tau_{i}^{K}=1-\frac{r^{*}}{\frac{\alpha(1-v) Y_{i}}{\bar{K}_{i}}-\delta_{i}}
\end{gathered}
$$

We assume an international real interest rate of $r^{*}=2 \%$. We obtain average capital depreciation rates by country from the Penn World Table.

Payroll tax rates and totalization agreements

Table A.3 shows examples of how to compute the effective rates for the U.S., Germany, Japan, and Chile. The effective tax rates are computed considering the average salary earned by U.S. nationals working in those countries with certificates of coverage. Table A.4 shows the analog information for foreign workers in the U.S. For the average earnings of foreign managers, we used the earnings projections computed by SSA. ${ }^{29}$

\footnotetext{
${ }^{29}$ The average earnings of foreign managers by nationality in the CPS was of similar value, but
} 
Table A.3: Example effective social security tax rates on average for Americans abroad, 2019

\begin{tabular}{|c|c|c|c|c|c|c|c|c|c|}
\hline \multirow[b]{2}{*}{$\begin{array}{l}\text { Destination } \\
\text { country }\end{array}$} & \multirow[t]{2}{*}{$\begin{array}{l}\text { Wage } \\
\text { ceiling } \\
\text { (USD) }\end{array}$} & \multirow[t]{2}{*}{$\begin{array}{c}\text { Tax } \\
\text { rate(\%) }\end{array}$} & \multirow{2}{*}{$\begin{array}{l}\text { Average } \\
\text { earnings } \\
\text { of } \\
\text { American } \\
\text { s abroad } \\
\text { under TA }\end{array}$} & \multicolumn{2}{|c|}{$\begin{array}{c}\text { Average } \\
\text { American abroad, } \\
\text { under TA, with } \\
\text { greater economic } \\
\text { attachment to the } \\
\text { foreign country }\end{array}$} & \multicolumn{2}{|c|}{$\begin{array}{c}\text { Average } \\
\text { American abroad, } \\
\text { under TA, with } \\
\text { greater economic } \\
\text { attachment to the } \\
\text { U.S. }\end{array}$} & \multicolumn{2}{|c|}{$\begin{array}{c}\text { Average } \\
\text { American abroad } \\
\text { without TA }\end{array}$} \\
\hline & & & & $\underset{\text { tax }}{\text { Implied }}$ & $\begin{array}{c}\text { Implied } \\
\text { tax rate } \\
(\%)\end{array}$ & $\underset{\text { tax }}{\text { Implied }}$ & $\begin{array}{c}\text { Implied } \\
\text { tax rate } \\
(\%)\end{array}$ & $\underset{\text { tax }}{\text { Implied }}$ & $\begin{array}{c}\text { Implied } \\
\text { tax rate } \\
(\%)\end{array}$ \\
\hline Japan & 382,163 & $17.80 \%$ & 332,000 & 59,096 & $17.8 \%$ & 27,296 & $8.2 \%$ & 86,392 & $26.0 \%$ \\
\hline Germany & 86,580 & $18.70 \%$ & 209,000 & 16,190 & $7.7 \%$ & 22,622 & $10.8 \%$ & 38,812 & $18.6 \%$ \\
\hline Chile & 36,000 & $13.50 \%$ & 232,000 & 4,860 & $2.1 \%$ & 23,496 & $10.1 \%$ & 28,356 & $12.2 \%$ \\
\hline US & 132,900 & $\begin{array}{r}12.4 \%+ \\
2.9 \%\end{array}$ & & & & & & & \\
\hline
\end{tabular}

Table A.4: Example effective social security tax rates on average for foreigners in the U.S., 2019

\begin{tabular}{|c|c|c|c|c|c|c|c|c|c|}
\hline \multirow[b]{2}{*}{$\begin{array}{l}\text { Origin } \\
\text { country }\end{array}$} & \multirow[b]{2}{*}{$\begin{array}{l}\text { Wage } \\
\text { ceiling }\end{array}$} & \multirow[b]{2}{*}{$\begin{array}{l}\% \\
\text { Tax } \\
\text { rate }\end{array}$} & \multirow[t]{2}{*}{$\begin{array}{l}\text { Average } \\
\text { earnings of } \\
\text { foreigners } \\
\text { in the US } \\
\text { under TA }\end{array}$} & \multicolumn{2}{|c|}{$\begin{array}{l}\text { Average } \\
\text { foreigner in the } \\
\text { US, under TA, } \\
\text { with greater } \\
\text { economic } \\
\text { attachment to } \\
\text { the foreign } \\
\text { country }\end{array}$} & \multicolumn{2}{|c|}{$\begin{array}{l}\text { Average } \\
\text { foreigner in the } \\
\text { US, under TA, } \\
\text { with greater } \\
\text { economic } \\
\text { attachment to the } \\
\text { U.S. }\end{array}$} & \multicolumn{2}{|c|}{$\begin{array}{c}\text { Average foreigner } \\
\text { in the US without } \\
\text { TA }\end{array}$} \\
\hline & & & & $\underset{\text { tax }}{\text { Implied }}$ & $\begin{array}{c}\text { Implied } \\
\text { tax rate } \\
(\%)\end{array}$ & $\underset{\text { tax }}{\text { Implied }}$ & $\begin{array}{l}\text { Implied } \\
\text { tax rate }\end{array}$ & $\underset{\text { tax }}{\text { Implied }}$ & $\begin{array}{c}\text { Implied } \\
\text { tax rate } \\
(\%)\end{array}$ \\
\hline Japan & 382,163 & $\begin{array}{r}17.80 \\
\%\end{array}$ & 121,630 & 21,650 & $17.8 \%$ & 18,609 & $15.3 \%$ & 40,260 & $33.1 \%$ \\
\hline Germany & 86,580 & $\begin{array}{r}18.70 \\
\%\end{array}$ & 121,630 & 16,190 & $13.3 \%$ & 18,609 & $15.3 \%$ & 34,800 & $28.6 \%$ \\
\hline Chile & 36,000 & $\begin{array}{r}13.50 \\
\% \\
\end{array}$ & 121,630 & 4,860 & $4.0 \%$ & 18,609 & $15.3 \%$ & 23,469 & $19.3 \%$ \\
\hline US & 132,900 & $\begin{array}{c}12.4 \\
\%+2 . \\
9 \% \\
\end{array}$ & & & & & & & \\
\hline
\end{tabular}

the sample size was very small. 
To choose the relevant tax rates for the simulation exercises, we assume greater economic attachment of Americans to the U.S. and of foreigners to the foreign country. For domestic taxes of foreigners, we assume foreigner managers earn the same salary in the U.S. as in their home countries, and compute effective rates as in Table A.4 above. $^{30}$

30 This depends on the country and year of the exercise. The average earnings of U.S. managers in the 2015 CPS was $\$ 115,009$ (below the $\$ 118,500$ cap for that year). Therefore, in the counterfactual for Germany, we use the nominal rate of $15.3 \%$ (12.4\% OASDI $+2.9 \%$ Medicare tax). 